\title{
Assessing the Environmental Hazard of Using Seawater for Ore Processing at the Lasail Mine Site in the Sultanate of Oman
}

\author{
Philipp Wanner • Mohammed Yasser Nasser Al-Sulaimani • \\ Niklaus Waber · Christoph Wanner
}

Received: 30 July 2013/Accepted: 2 July 2014/Published online: 7 August 2014

(c) Springer-Verlag Berlin Heidelberg 2014

\begin{abstract}
The Lasail mining area (Sultanate of Oman) was contaminated by acid mine drainage during the exploitation and processing of local and imported copper ore and the subsequent deposition of sulphide-bearing waste material into an unsealed tailings dump. In this arid environment, the use of seawater in the initial stages of ore processing caused saline contamination of the fresh groundwater downstream of the tailings dump. After detection of the contamination in the 1980s, different source-controlled remediation activities were conducted including a seepage water collection system and, in 2005, surface sealing of the tailings dump using an HDPE-liner to prevent further infiltration of meteoric water. We have been assessing the benefits of the remediation actions undertaken so far. We present chemical and isotopic $\left(\delta^{18} \mathrm{O}, \delta^{2} \mathrm{H},{ }^{3} \mathrm{H}\right)$ groundwater data from a long-term survey (8-16 years) of the Wadi Suq aquifer along a $28 \mathrm{~km}$ profile from the tailings dump to the Gulf of Oman. Over this period, most metal concentrations in the Wadi Suq groundwater decreased below detection limits. In addition, in the first boreholes downstream of the tailings
\end{abstract}

Electronic supplementary material The online version of this article (doi:10.1007/s10230-014-0281-9) contains supplementary material, which is available to authorized users.

P. Wanner $(\bowtie) \cdot$ M. Y. N. Al-Sulaimani · N. Waber RWI, Institute of Geological Sciences, University of Bern, Baltzerstrasse 1-3, 3012 Bern, Switzerland

e-mail: philipp.wanner@unine.ch

M. Y. N. Al-Sulaimani

Earth Secrets, 4494, 19584 Al-Athiaibah, Sultanate of Oman

C. Wanner

Earth Sciences Division, Lawrence Berkeley National

Laboratory, 1 Cyclotron Rd, Berkeley, CA 94720, USA pond, the salinity contamination has decreased by $30 \%$ since 2005. This decrease appears to be related to the surface coverage of the tailings pond, which reduces flushing of the tailings by the sporadic, but commonly heavy, precipitation events. Despite generally low metal concentrations and the decreased salinity, groundwater quality still does not meet the WHO drinking water guidelines in more than $90 \%$ of the Wadi Suq aquifer area. The observations show that under arid conditions, use of seawater for ore processing or any other industrial activity has the potential to contaminate aquifers for decades.

Keywords Acid mine drainage (AMD) - Groundwater contamination $\cdot$ Salinity contamination $\cdot$ Remediation

\section{Introduction}

Acid mine drainage (AMD) is caused by the weathering of metal sulphides. The various clean-up strategies proposed and applied to remediate AMD-contaminated sites can be roughly divided into "migration control" and "source control" approaches (Johnson and Hallberg 2005). The "migration control" approach includes active or passive treatment of the AMD (Byrne et al. 2011). The "source control" approach limits AMD formation at its source, typically by preventing contact of atmospheric oxygen or water with sulphide minerals to prevent weathering (Johnson and Hallberg 2005). Examples include the isolation of tailings from the atmosphere and subsurface using natural or artificial liners of different compositions, such as clay or high-density polyethylene, HDPE (e.g. Breitenbach and Smith 2006) and underwater storage of tailings ( $\mathrm{Li}$ et al. 1997). 
This study presents long-term monitoring results of groundwater contamination induced by copper ore mining at the Lasail mine site in the upstream area of Wadi Suq (Sohar district, Sultanate of Oman). The observed groundwater contamination is two-fold in that it has a component of "normal" AMD induced by weathering of the sulphidic tailings, and a salinity component as a result of seawater having been used for ore processing. Seawater was used because of the scarcity of fresh water in this arid area. Although the use of seawater was abandoned in 1993, it still represents a major portion of the porewater in the tailings. Migration control remediation activities were undertaken in 1983 and again in 1992 by installing cut-off trenches about 400 and $500 \mathrm{~m}$ downstream of the tailings pond (Sharama and Al-Busaidi 2001). From these trenches, the saline seepage water was pumped into bottom-sealed ponds and allowed to evaporate. Based on recommendations made during the first monitoring phase of this study, a "source control" remediation approach was also applied; the tailings were surface-sealed with an HDPE liner in 2005.

Chemical and isotopic groundwater data are reported from four different sampling campaigns (2004, 2005, 2011, and 2012) to assess the impact of the tailings covering in 2005 on groundwater quality in Wadi Suq, downstream of the tailings pond. Groundwater data are supported by chemical and mineralogical analyses of tailings material to generally improve understanding of the geochemical system of the contamination in the area.

\section{Site Description}

\section{Climate}

The climate of Northern Oman (Fig. 1) is classified as 'arid' and is characterised by a generally low humidity (average ca. $30 \%$ ), high evaporation rates $(5-15 \mathrm{~mm} /$ day; Lakey et al. 1995), and a mean annual temperature of $30-31{ }^{\circ} \mathrm{C}$ in the Sohar area. Variations in humidity are related to erratic rainfall events, which commonly occur between December and March from Mediterranean frontal systems approaching the area from the north and northwest (Weyhenmeyer et al. 2002). Local convective storm cells develop over the mountains during the summer months and are a second source of precipitation. Additionally, in periods of about 5-10 years, tropical depression cyclones that originate either in the southeastern Arabian Sea or the Bay of Bengal may cause occasionally heavy precipitation for several days.

The amount of rainfall is monitored by the Omani Ministry of Transport and Communications in Wadi Suq, close to borehole D9 (Fig. 1) near the coast. Over the past 12 years, the annual precipitation in the area has been less than the 31 year long-term average (94 mm/year), except for 2009 (Fig. S-1). (Supplemental figures and tables, indicated by the $\mathrm{S}$ such as here, appear with the on-line version of this paper, and can be downloaded for free by all subscribers.) The first groundwater monitoring campaign in 1996 by the Omani Ministry of Water Resources (MWR 1996) took place during a period with unusually high amounts of precipitation. In contrast, campaigns conducted after 2000 correspond to a drier period compared to the long-term average (Fig. S-1).

\section{Hydrogeology}

The catchment of the Wadi Suq aquifer covers an area of ca. $550 \mathrm{~km}^{2}$ and is located in the northern part of the Sultanate of Oman (Fig. 1). General groundwater flow in the aquifer is directed from southwest to northeast with an average hydraulic gradient of 0.008 (Fig. 1; JICA and MCI 2001). The catchment can be divided into three hydrogeological units. The upstream part is made of extrusive rocks of the Semail Ophiolite (Le Métour 1995; Fig. 1), where groundwater flow is controlled by fracture porosity. Based on borehole data, the transmissivity of this upstream part ranges between $10^{-6}$ and $10^{-7} \mathrm{~m}^{2} / \mathrm{s}$ (JICA and MCI 2001; Table S-1), with the water table 7 to $10 \mathrm{~m}$ below the surface (Table S-1). The extrusive rock unit in Wadi Suq consists of basaltic and andesitic pillow lava and massive lava flows and is mainly composed of the primary minerals plagioclase and clinopyroxene and secondary minerals such as albite, actinolite, carbonates, chlorite, quartz, and zeolites (Einaudi et al. 2000; Glennie et al. 1974; Lippard 1986; Peters et al. 1990). These rocks form the hilly landscape, which is frequently incised by more or less deep wadi channels, with Wadi Suq being the largest. These channels are filled with fluvial sediments and act as major groundwater flow paths. In the upstream part of the Wadi Suq catchment, the fluvial sediments reach a thickness of several meters and are composed of more or less altered ophiolitic rock debris.

In the middle part of Wadi Suq towards the east, the bedrock lithology changes to the sedimentary sequence of the Hawasina Group (Fig. 1) and includes radiolarian chert, minor sandstone, oolithic calcarenite, and carbonate turbidites (Béchennec et al. 1988; Glennie et al. 1974; Le Métour 1995). In these rocks, groundwater flow is mainly controlled by dissolution porosity. The average transmissivity is on the order of $10^{-5}-10^{-6} \mathrm{~m}^{2} / \mathrm{s}$ (JICA and MCI 2001; Table S-1) and the groundwater table ranges between 3.5 and $7.5 \mathrm{~m}$ below the surface (Table $\mathrm{S}-1$ ).

The lowest part of Wadi Suq towards the coast is characterised by alluvial sediments several hundreds of meters thick that have accumulated since the obduction of the Semail ophiolite, and minor post-obduction carbonaceous sediments (Le Métour 1995). The alluvial sediments 


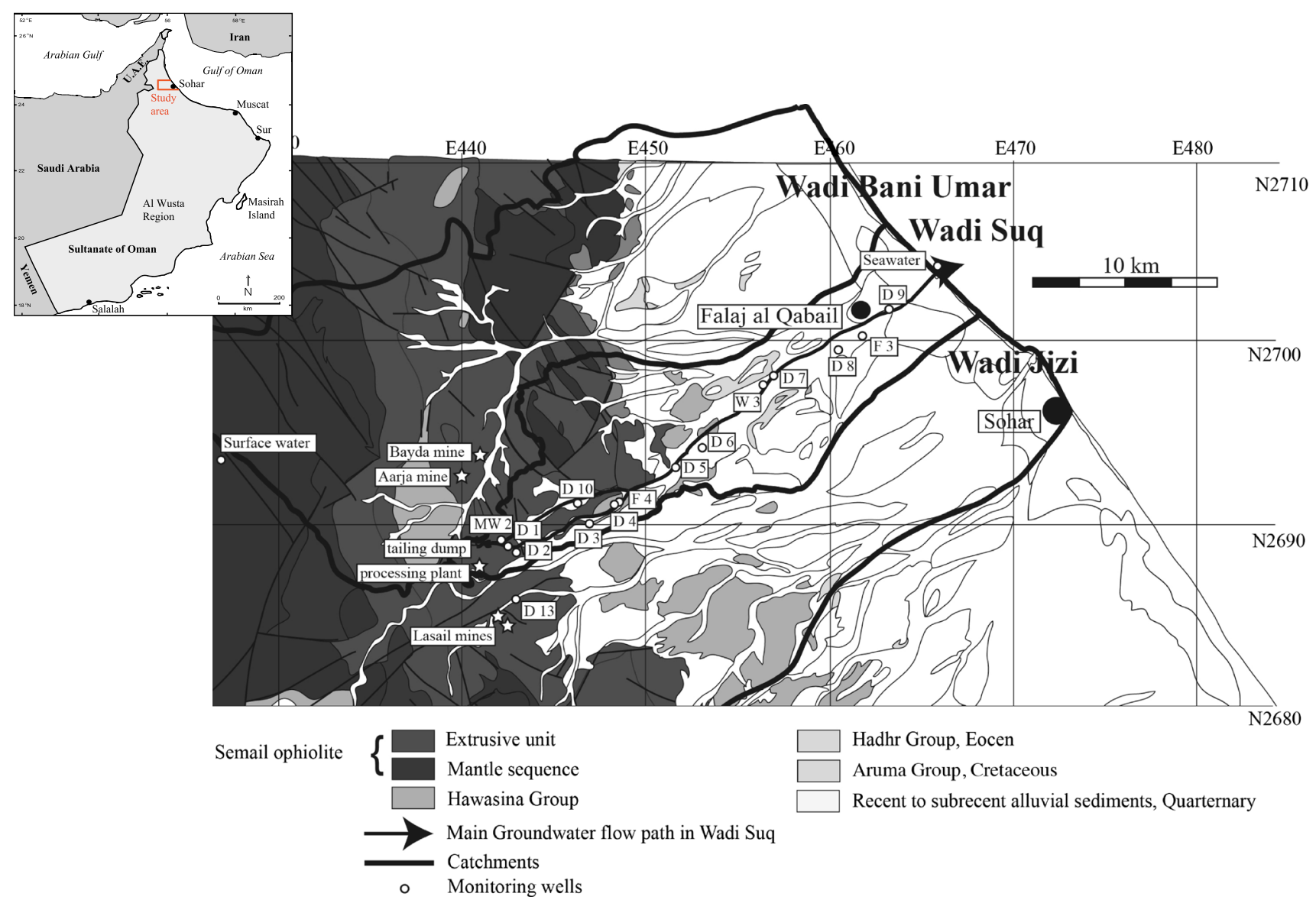

Fig. 1 Geological map of the Sohar area (modified after Le Métour 1995) showing the catchments of Wadi Suq, Wadi Bani Umar and Wadi al Jizi and groundwater sampling locations. The inserted small

mainly consist of boulder beds, partially-cemented gravels, and unconsolidated sands (Gibb and Partners 1974; Weyhenmeyer 2000). The larger components of these conglomerates consist of rock debris from the ophiolitic mountain range and its sedimentary foothills in the west. They are often tightly cemented with secondary dolomite and high- and low-magnesium calcite (Burns and Matter 1995). Groundwater flow in these sediments is mainly controlled by heterogeneously and homogeneously distributed inter-granular porosity. The heterogeneous nature of the sediments results in a range of transmissivity between about $10^{-4}$ and $10^{-7} \mathrm{~m}^{2} / \mathrm{s}$ (JICA and MCI 2001). The groundwater table in the investigated boreholes ranged between 5 and $21 \mathrm{~m}$ below the surface (Table S-1).

History of Mining Activities and Groundwater Contamination

The groundwater contamination by AMD and seawaterbased processing water has its origin at the Lasail ore processing plant and its unsealed tailings pond at the map (after Weyhenmeyer et al. 2002) shows the study area in the regional geographical context

beginning of Wadi Suq (Fig. 1). The Oman Mining Company (OMC) started mining and processing local copper in 1982. By 1994, when the local ore resources were exhausted, about 11 Mio tons of tailings material had been deposited into the uppermost wadi channel that served as an unsealed tailings dump, initially without a seepage water collection system (Sharama and Al-Busaidi 2001). From 1983 to 1993, seawater was used as a processing fluid and this seawater-based processing fluid was disposed into the tailings dump along with the sulphide-bearing solid residue. During this operational stage, about 5 Mio $\mathrm{m}^{3}$ of seawater were pumped into the tailings pond (MWR 1996). The contamination of the Wadi Suq groundwater by saline processing fluid was recognised soon after commission of the tailings pond in 1983. In the same year, a cut-off trench was installed some $400 \mathrm{~m}$ downstream of the tailings dam to collect the saline seepage water and pump it into specially-designed evaporation ponds (Sharama and AlBusaidi 2001). As this initial remediation action was not successful, a second cut-off trench was installed in 1992, again with limited success. Based on that, the use of 
seawater as a processing fluid ceased in 1993, and in 1994 the activities at the Lasail ore processing plant were reduced to smelting and electrolytic refinement of imported copper ore. Tailings were still disposed of in the existing pond until 2006 when a new, bottom-sealed tailings pond was constructed in a side channel of a neighbouring wadi. Based on recommendations made during the first monitoring phase of the present study, a source control remediation approach was applied and the original tailings pond was surface-sealed with an HDPE liner in 2005.

In 1996, the Ministry of Water Resources of Oman (MWR) initiated a groundwater survey across the entire Wadi Suq aquifer to assess the extent of the pollution (MWR 1996). At that time, the front of the salinity plume was identified about $12 \mathrm{~km}$ from the tailings dump (Fig. 1, borehole D4) confirming that a fully-connected groundwater system occurs along Wadi Suq. Elevated concentrations of $\mathrm{Cu}, \mathrm{Fe}, \mathrm{Pb}, \mathrm{Mn}$, and $\mathrm{Zn}$ were observed in the seepage water of the cut-off trenches and in groundwater within the first few kilometres of the tailings dump, whereas concentrations of $\mathrm{Cd}$ and $\mathrm{Cr}$ were below detection limits (MWR 1996). In addition, a secondary source of salinity contamination was suspected upstream of borehole D5 due to leaking of the seawater pipeline, which was constructed along the wadi to supply the processing plant with seawater. In 2001, a Japanese consortium and the Omani Ministry of Commerce and Industry conducted a follow-up evaluation of the impact of mining on the groundwater quality in Wadi Suq (JICA and MCI 2001). At that time, the front of the salinity plume was $14 \mathrm{~km}$ downstream of the tailings pond. Again, elevated metal concentrations were observed in groundwater sampled in the neighbourhood of the tailings dump and the existence of a second salinity source upstream of borehole D5 was confirmed.

Until the discovery of the contamination in 1983, groundwater in Wadi Suq was used for drinking water and irrigation by local farmers in the upper and middle part and by a large population in Falaj al Qabail in the lower part (Fig. 1). At present, groundwater is no longer used to supply drinking water and is only used for irrigation in the coast-near area east of Falaj al Qabail (near-by borehole D9 in Fig. 1).

\section{Methods}

\section{Solid Material Analyses}

Tailings material was collected as average samples across a $4 \mathrm{~m}$ deep drainage trench on top of the tailings pond in 2004. These samples (ca. $5 \mathrm{~kg}$ ) were homogenised and dried at $40{ }^{\circ} \mathrm{C}$ and not at higher temperature to prevent the formation of secondary mineral phases. Subsequently, an aliquot of $200 \mathrm{~g}$ of dried, fine-grained tailings material was pulped to a grain size $<2 \mu \mathrm{m}$ using a disc mill. Mineralogical investigations were performed by $\mathrm{X}$-ray powder diffraction analysis (XRD) using a Panalytical CubiX ${ }^{3}$ diffractometer with Cu $\alpha$-radiation $(\lambda=1.54598 \AA)$ and the software HighScorePlus. The chemical composition of the tailings material was semi-quantitatively analysed by x-ray fluorescence analysis using a Philips PW2400 spectrometer and UNIQUANT software, following the procedure described by Eggimann (2008).

\section{Groundwater Chemical and Isotope Analyses}

Groundwater from the Wadi Suq aquifer was sampled from boreholes located along a profile from the Lasail tailings pond towards the coast (Fig. 1) in four sampling campaigns during 2004, 2005, 2011, and 2012. The accessibility of boreholes and private wells varied over these years and not every borehole could be sampled in every campaign. Sampling further included surface water and groundwater from Wadi al Jizi (borehole D13, Fig. 1) outside the Wadi Suq catchment.

Groundwater was collected from boreholes using a bailer-sampling system in 2004 and by pumping using a submersible GRUNDFOS MP1 pump during all later sampling campaigns. Water levels were monitored during the entire pumping activity. Sampling began with removal of stagnant groundwater in the boreholes by pumping of 20-40 L, a volume corresponding to at least one borehole volume for most boreholes. After recovery of the water table, groundwater was collected for field measurements and in HDPE bottles for laboratory analyses. Groundwater in the sample bottle reserved for cation analysis was acidified to a $\mathrm{pH}$ of $2-3$ by adding nitric acid $\left(\mathrm{HNO}_{3}\right)$. Onsite measurements of electric conductivity (EC), $\mathrm{pH}, \mathrm{Eh}$, and $\mathrm{O}_{2}$ content were conducted using Knick measurement devices equipped with Hamilton electrodes. Eh values were measured using a Hamilton Oxytrode PTI $120 \mathrm{Pt}-\mathrm{Ag} / \mathrm{AgCl}$ electrode. Measured values were later corrected relative to the standard hydrogen electrode (SHE), according to Nordstrom and Wilde (1998).

Major anions and cations $\left(\mathrm{Na}^{+}, \mathrm{K}^{+}, \mathrm{Ca}^{2+}, \mathrm{Mg}^{2+}, \mathrm{Sr}^{2+}\right.$, $\mathrm{F}^{-}, \mathrm{Cl}^{-}, \mathrm{Br}^{-}, \mathrm{SO}_{4}{ }^{2-}, \mathrm{NO}_{3}{ }^{-}$) were analysed by ion chromatography (IC) using a Methrohm 861 Advanced Compact IC system with detection limits of $<1.0 \mathrm{mg} / \mathrm{L}$ for cations and $<0.5 \mathrm{mg} / \mathrm{L}$ for anions. The analytical error based on multiple measurements of certified standard solutions (AccuSPEC Standard SCP Science, Fluka/SigmaAldrich No 89886 and 89316) was $\pm 5 \%(1 \sigma)$ for concentrations up to $1 \mathrm{~g} / \mathrm{L}$ and $\pm 10 \%(1 \sigma)$ for concentrations up to $10 \mathrm{~g} / \mathrm{L}$. Depending on the element, the samples were gravimetrically diluted $10 \times, 100 \times$, or $1,000 \times$. Based on 
the precision of the balance $( \pm 0.01 \mathrm{mg})$, the additional error induced by dilution is at most $1.4 \%$, according to Gauss' error propagation. Groundwater alkalinity was determined using a $0.02 \mathrm{M} \mathrm{HCl}$ titration technique using a Methrohm 785 DMP Titrino.

For the sampling campaigns of 2004 and 2005, selected trace elements in groundwater were analysed by ICP-OES (Perkin-Elmer) the Omani Director General of Minerals Laboratory (Ministry of Commerce and Industry). The reported detection limit and analytical error of these analyses was $<0.02 \mathrm{mg} / \mathrm{L}$ and $\pm 10 \%$, respectively. For the sampling campaigns of 2011 and 2012, trace elements were analysed by ICP-OES (Varian 720 ES) with detection limits of $<0.02$ for $\mathrm{Ba}, \mathrm{Cd}$, and $\mathrm{Cr},<0.05 \mathrm{mg} / \mathrm{L}$ for $\mathrm{Al}, \mathrm{As}, \mathrm{Cu}, \mathrm{Fe}, \mathrm{Ni}$, and $\mathrm{Pb}$, and $<0.2 \mathrm{mg} / \mathrm{L}$ for $\mathrm{Zn}$. The error of these measurements $(1 \sigma)$ is $\pm 5 \%$ for $\mathrm{Cu}, \pm 5-20 \%$ for $\mathrm{Al}, \mathrm{Fe}, \mathrm{Ni}$, and $\mathrm{Zn}$, and $\pm 10-20 \%$ for $\mathrm{As}, \mathrm{Ba}, \mathrm{Cd}, \mathrm{Cr}$, and $\mathrm{Pb}$, based on multiple measurements of certified standard solutions (Merck ICP Multi-element-Standards CertiPur IV and X).

Isotope measurements were performed by Hydroisotop $\mathrm{GmbH}$ (Schweitenkirchen, Germany) using isotope ratio mass spectrometry (IRMS). Results of stable oxygen and hydrogen isotopes are reported in the delta notation as $\delta^{18} \mathrm{O}$ and $\delta^{2} \mathrm{H}$ relative to the VSMOW standard (Vienna Standard Mean Ocean Water). For these analyses the $1 \sigma$ error is $\pm 0.15 \%$ for $\delta^{18} \mathrm{O}$ and $\pm 1.5 \%$ or $\delta^{2} \mathrm{H}$. Tritium analyses were performed by liquid scintillation counting after electrolytic enrichment and reported as tritium units (1 $\mathrm{TU}=0.119 \mathrm{~Bq} / \mathrm{L}$ ) with a detection limit of $0.6 \mathrm{TU}$.

\section{Geochemical Modelling}

Aqueous speciation and mineral saturation indices ( $\mathrm{SI}=\log$ $\mathrm{IAP} / \mathrm{K}_{\mathrm{sp}}$; where IAP $=$ ion activity product, $\mathrm{K}_{\mathrm{sp}}=$ solubility product constant) of fast-reacting minerals such as calcite, celestite, dolomite, fluorite, gypsum, magnesite, and strontianite were calculated from aqueous concentrations using the computer code PHREEQC (Parkhurst and Appelo 1999; v. $2.18,2011)$ and thermodynamic data tabulated in the WATEQ4 database (Ball and Nordstrom 1991; Nordstrom et al. 1990; v.431 2005). The ionic strength of all groundwater samples is $<0.9 \mathrm{~mol} / \mathrm{kg}_{\mathrm{H}_{2} \mathrm{O}}$ and for most of them $<0.7 \mathrm{~mol} / \mathrm{kg}_{\mathrm{H}_{2} \mathrm{O}}$. This justifies the application of the extended Debye-Hückel formalism for activity coefficient correction and thus the use of the WATEQ4F database.

\section{Results}

\section{Composition of Tailings}

The composition of tailings deposited in the tailings pond was heterogeneous and varied over time. In the initial stages of ore processing at the Lasail ore processing plant, copper ore from local mines was processed and the wall rock material was ophiolitic in origin. Since the exploitation of the local ore resources in 1993, imported copper ore from various sources and of unknown wall rock composition has been processed. Only the uppermost $4 \mathrm{~m}$ of the tailings pond were accessible for sampling with tailings originating from imported ore. This material consists mainly of sulphide (pyrite, pentlandite, sphalerite) and sulphate minerals (jarosite, gypsum, epsomite) besides quartz and other minor wall rock minerals (Fig. S-2). Based on the mineralogical composition, oxidative weathering of remnant sulphide ore minerals with subsequent formation of secondary sulphates is a dominant process at the surface of the tailings pond. Secondary jarosite is typical for low $\mathrm{pH}$ conditions created by sulphide oxidation (e.g. Bigham and Nordstrom 2000; Bladh 1982) and gypsum and epsomite are typical secondary mineral phases at AMD sites (e.g. McGregor and Blowes 2002).

Chemical analyses of the tailings material reveal almost equal concentrations of $\mathrm{Ca}$ and $\mathrm{Mg}$ in the grain-size fraction of 100-200 $\mu \mathrm{m}$ and the whole rock (Table S-2). This suggests that in the upper levels of the tailings pond, these compounds are available for the formation of secondary $\mathrm{Ca}-$ and $\mathrm{Mg}$-bearing sulphates, such as gypsum and epsomite. In the upper part of the pond with tailings originating from imported ore, the major source of $\mathrm{Ca}^{2+}$ and $\mathrm{Mg}^{2+}$ for the formation of secondary sulphate minerals is the carbonate added to the tailings as a pH-neutralising reagent, as indicated by $\mathrm{Sr}$ isotope investigations (Al-Sulaimani 2005). Ophiolitic wall rock and the seawater used for ore processing are additional sources of $\mathrm{Ca}^{2+}$ and $\mathrm{Mg}^{2+}$ in the lower part of the pond, representing tailings from local ore resources.

Consistent with the mineralogy, high concentrations of Fe and $\mathrm{S}$ indicate that pyrite comprises a substantial part of the tailings material. Other metal concentrations are relatively low, except for $\mathrm{Cu}$ and $\mathrm{Zn}$ (Table S-2). The inventory of metals in the uppermost $4 \mathrm{~m}$ of the tailings thus appears limited, except for $\mathrm{Cu}$ and $\mathrm{Zn}$. In the lower levels of the tailings, chromium associated with the ophiolitic wall rock of the local ore exploitation also occurs.

\section{Groundwater Data}

Within the observation period from 2004 to 2012, the total dissolved solids (TDS) content of Wadi Suq groundwater changes from $>30 \mathrm{~g} / \mathrm{L}$ within $2 \mathrm{~km}$ of the tailings dam to $<1 \mathrm{~g} / \mathrm{L}$ close to the discharge into the Gulf of Oman (Table 1). Groundwater within $2 \mathrm{~km}$ of the tailings dam, with TDS contents $>30 \mathrm{~g} / \mathrm{L}$, is of a general $\mathrm{Na}-\mathrm{Ca}-\mathrm{Mg}-\mathrm{Cl}$ chemical type, with variable amounts of $\mathrm{Ca}^{2+}$ and $\mathrm{Mg}^{2+}$. It is enriched in ${ }^{18} \mathrm{O}$ and ${ }^{2} \mathrm{H}$ compared to seawater and 
displays elevated ${ }^{3} \mathrm{H}$ contents (Table 1 ). When this highly mineralised seepage water enters the main channel of Wadi Suq about $4 \mathrm{~km}$ from the tailings dam, the mineralisation decreases to about $10-16 \mathrm{~g} / \mathrm{L}$, as illustrated by groundwater collected from boreholes D3 and D4 at 6.6 and $8.5 \mathrm{~km}$, respectively. While still a general $\mathrm{Na}-\mathrm{Ca}-\mathrm{Mg}-\mathrm{Cl}$ chemical type, dilution of the highly mineralised seepage water by fresh groundwater is indicated by less enriched $\delta^{18} \mathrm{O}$ and $\delta^{2} \mathrm{H}$ values and lower ${ }^{3} \mathrm{H}$ contents (Table 1 ). In addition, a separation into a lower and upper groundwater flow is indicated in boreholes D4S (sampling depth $10 \mathrm{~m}$ ) and D4D (sampling depth $28 \mathrm{~m}$ ) at $8.5 \mathrm{~km}$. There, the shallower, more mineralised groundwater displays positive $\delta^{18} \mathrm{O}$ and $\delta^{2} \mathrm{H}$ values and elevated ${ }^{3} \mathrm{H}$ contents, whereas the deeper groundwater has negative $\delta^{18} \mathrm{O}$ and $\delta^{2} \mathrm{H}$ values and ${ }^{3} \mathrm{H}$ contents around or below detection. The latter indicates that the fresh water component of the deeper groundwater has a longer average residence time than the component dominated by seepage water. In the upper third of Wadis Suq, changes in the TDS content were found only in groundwater of borehole D3 (30\% increase, $6.6 \mathrm{~km}$ from the tailings dam) and the deeper groundwater of borehole 4D (8.5 km distance, $20 \%$ increase), whereas it remained rather constant at the other locations between the sampling campaigns from 2004 to 2012 (Table 1).

The general decrease in groundwater mineralisation over the first $8.5 \mathrm{~km}$ from the tailings dam was interrupted by highly elevated TDS in borehole D5 at $12.9 \mathrm{~km}$ (Table 1). The $\mathrm{Na}-\mathrm{Ca}-\mathrm{Cl}$ type groundwater of this borehole was again characterised by positive $\delta^{18} \mathrm{O}$ and $\delta^{2} \mathrm{H}$ values and elevated ${ }^{3} \mathrm{H}$ contents, similar to those of the seepage water adjacent to the tailings dam. In contrast to the upstream boreholes, the total mineralisation in borehole D5 decreased by about $25 \%$ from 2004 to 2011 . Chemical and isotope composition of groundwater from borehole D5 suggest a similar salinity source as the highly mineralised seepage water, i.e. seawater.

Downstream of the sedimentary rocks of the Hawasina Group, Wadi Suq gets wider and enters the alluvial plain (Fig. 1). Here groundwater mineralisation gradually decreases to $<1 \mathrm{~g} / \mathrm{L}$ and changes to a $\mathrm{Mg}-\mathrm{Na}-\mathrm{Ca}-\mathrm{Cl}-$ $\mathrm{HCO}_{3}-\mathrm{SO}_{4}$ chemical type at about $28 \mathrm{~km}$ from the tailings dam (borehole D9). Over time (i.e. between 2004 and 2012), however, the TDS content of groundwater in a specific borehole increased up to $50 \%$ in the interval from borehole D6 $(14.9 \mathrm{~km})$ to borehole D8 $(24.8 \mathrm{~km})$, mainly as a result of increased $\mathrm{Na}^{+}$and $\mathrm{Cl}^{-}$concentrations (Table $\mathrm{S}-4)$. In most of this groundwater, the increase in mineralisation was accompanied by enrichment in ${ }^{18} \mathrm{O}$ and ${ }^{2} \mathrm{H}$ and a decrease in the ${ }^{3} \mathrm{H}$ contents (Table 1). As already observed in the upper part of the wadi, separation into a lower and upper groundwater flow was again indicated at borehole D6, $14.9 \mathrm{~km}$ from the tailings dam. Similar to the upstream borehole, D4, the deeper groundwater in borehole D6D (sampling depth $25 \mathrm{~m}$ ) was less mineralised, had more negative $\delta^{18} \mathrm{O}$ and $\delta^{2} \mathrm{H}$ values, and ${ }^{3} \mathrm{H}$ contents around or below detection, indicating a longer average residence time for the fresh water component than the shallow groundwater in borehole D6S (sampling depth $15 \mathrm{~m})$.

Elevated metal concentrations between 0.05 and $1.9 \mathrm{mg} /$ $\mathrm{L}$ were found for $\mathrm{Cd}, \mathrm{Cr}, \mathrm{Cu}, \mathrm{Fe}, \mathrm{Ni}, \mathrm{Pb}$, and $\mathrm{Zn}$ in groundwater with TDS concentrations $>10 \mathrm{~g} / \mathrm{L}$ down to borehole D5 at $12.9 \mathrm{~km}$ from the dam in the sampling campaigns of 2004 and 2005 (Table 1). During the campaigns of 2011 and 2012, however, metal concentrations in the groundwater generally decreased to below the detection limit, except for $\mathrm{Cu}, \mathrm{Fe}$, and $\mathrm{Zn}$ (Table 1). In Wadi Suq groundwater collected from within the alluvial plain, the metal concentrations were around or below detection over the entire observation period.

Despite the absence of pronounced metal contamination at distances of more than about $6 \mathrm{~km}$ from the tailings dam, the Wadi Suq groundwater is no longer suitable as drinking or irrigation water up to $20 \mathrm{~km}$ from the tailings dam. Groundwater in Wadi Suq has $\mathrm{Na}^{+}, \mathrm{Cl}^{-}, \mathrm{SO}_{4}{ }^{2-}$, and TDS concentrations far above the WHO drinking water guidelines (WHO 2011), except for the groundwater from the most downstream borehole, D9, near the coast (Fig. 1; Table 1).

Within this context, the special climatic conditions of the Wadi Suq area need to be recognised. The limited and often erratic precipitation, combined with high evaporation rates and the proximity to the sea to the east and north and the desert to the west, results in a larger impact of sea spray and eolian sediments on infiltrating groundwater than, for example in Mediterranean environments. Therefore, the extent of the deviation of groundwater compositions from Wadi Suq from the regional natural background was evaluated by comparing Wadi Suq groundwater to groundwater unaffected by anthropogenic activities and collected from similar geological environment such as the Batinah Coastal Plane (Weyhenmeyer 2000, 2002) and the Jabal Akhdar-Adam Mountains area (Matter 2001; Matter et al. 2005; Rathmayr 2000). This comparison allows for the natural compositional variability of groundwater in northern Oman when classifying the Wadi Suq groundwater as contaminated and noncontaminated. Based on these criteria, only groundwater from borehole D8 collected in 2004 and groundwater from borehole D9 collected between 2004 and 2012 can be considered as non-contaminated in Wadi Suq (Figs. 2, 3 ). Both these boreholes are located within the alluvial plain at the greatest distance from the ore processing plant and tailings pond. Similarly, surface- and ground-water from borehole D13, located in the hydraulically 
Table 1 Chemical and isotopic data of groundwater samples collected in Wadi Suq (WS) and neighbouring localities between 2004 and 2012

\begin{tabular}{|c|c|c|c|c|}
\hline Borehole & Sampling date & Location & Distance from tailings dump (km) & Water type \\
\hline \multirow[t]{2}{*}{ D1 } & Jun 2004 & Wadi Suq & 0.1 & $\mathrm{Na}-\mathrm{Ca}-\mathrm{Cl}$ \\
\hline & Jan 2005 & Wadi Suq & 0.1 & $\mathrm{Na}-\mathrm{Ca}-\underline{\mathrm{Cl}}$ \\
\hline MW2 & Jan 2011 & Wadi Suq & 0.4 & $\underline{\mathrm{Na}}-\mathrm{Ca}-\underline{\mathrm{Cl}}$ \\
\hline \multirow[t]{2}{*}{ D2 } & Jun 2004 & Wadi Suq & 2.0 & $\underline{\mathrm{Ca}}-\mathrm{Mg}-\mathrm{Na}-\underline{\mathrm{Cl}}$ \\
\hline & Jan 2005 & Wadi Suq & 2.0 & $\underline{\mathrm{Ca}}-\mathrm{Mg}-\mathrm{Na}-\underline{\mathrm{Cl}}$ \\
\hline \multirow[t]{4}{*}{ D3 } & Jun 2004 & Wadi Suq & 6.6 & $\mathrm{Na}-\mathrm{Ca}-\mathrm{Mg}-\underline{\mathrm{Cl}}$ \\
\hline & Jan 2005 & Wadi Suq & 6.6 & $\underline{\mathrm{Na}}-\mathrm{Ca}-(\mathrm{Mg})-\underline{\mathrm{Cl}}$ \\
\hline & Jan 2011 & Wadi Suq & 6.6 & $\underline{\mathrm{Na}}-\mathrm{Ca}-(\mathrm{Mg})-\underline{\mathrm{Cl}}$ \\
\hline & Jan 2012 & Wadi Suq & 6.6 & $\underline{\mathrm{Na}}-\mathrm{Ca}-(\mathrm{Mg})-\underline{\mathrm{Cl}}$ \\
\hline \multirow[t]{3}{*}{$\mathrm{D} 4 \mathrm{~S}$} & Jan 2005 & Wadi Suq & 8.5 & $\mathrm{Na}-\mathrm{Ca}-\mathrm{Mg}-\underline{\mathrm{Cl}}$ \\
\hline & Jan 2011 & Wadi Suq & 8.5 & $\mathrm{Na}-\mathrm{Mg}-\mathrm{Ca}-\underline{\mathrm{Cl}}$ \\
\hline & Jan 2012 & Wadi Suq & 8.5 & $\mathrm{Na}-\mathrm{Mg}-\mathrm{Ca}-\underline{\mathrm{Cl}}$ \\
\hline \multirow[t]{3}{*}{ D4D } & Jun 2004 & Wadi Suq & 8.5 & $\underline{\mathrm{Na}}-\mathrm{Ca}-\underline{\mathrm{Cl}}$ \\
\hline & Jan 2011 & Wadi Suq & 8.5 & $\underline{\mathrm{Ca}}-\mathrm{Na}-\underline{\mathrm{Cl}}-\left(\mathrm{SO}_{4}\right)$ \\
\hline & Jan 2012 & Wadi Suq & 8.5 & $\underline{\mathrm{Ca}}-\mathrm{Na}-\underline{\mathrm{Cl}}-\left(\mathrm{SO}_{4}\right)$ \\
\hline \multirow[t]{3}{*}{ D5 } & Jun 2004 & Wadi Suq & 12.9 & $\underline{\mathrm{Na}}-\mathrm{Ca}-\underline{\mathrm{Cl}}$ \\
\hline & Jan 2005 & Wadi Suq & 12.9 & $\underline{\mathrm{Na}}-\mathrm{Ca}-\underline{\mathrm{Cl}}$ \\
\hline & Jan 2011 & Wadi Suq & 12.9 & $\underline{\mathrm{Na}}-\mathrm{Ca}-(\mathrm{Mg})-\underline{\mathrm{Cl}}$ \\
\hline \multirow[t]{4}{*}{ D6S } & Jun 2004 & Wadi Suq & 14.9 & $\mathrm{Na}-\mathrm{Mg}-\mathrm{Ca}-\underline{\mathrm{Cl}}$ \\
\hline & Jan 2005 & Wadi Suq & 14.9 & $\mathrm{Na}-\mathrm{Mg}-\mathrm{Ca}-\underline{\mathrm{Cl}}$ \\
\hline & Jan 2011 & Wadi Suq & 14.9 & $\mathrm{Na}-\mathrm{Ca}-\mathrm{Mg}-\underline{\mathrm{Cl}}$ \\
\hline & Jan 2012 & Wadi Suq & 14.9 & $\mathrm{Na}-\mathrm{Ca}-\mathrm{Mg}-\underline{\mathrm{Cl}}$ \\
\hline \multirow[t]{2}{*}{ D6D } & Jan 2011 & Wadi Suq & 14.9 & $\mathrm{Na}-\mathrm{Ca}-\mathrm{Mg}-\underline{\mathrm{Cl}}$ \\
\hline & Jan 2012 & Wadi Suq & 14.9 & $\underline{\mathrm{Na}}-\mathrm{Mg}-\mathrm{Ca}-\underline{\mathrm{Cl}}$ \\
\hline \multirow[t]{3}{*}{ W3 } & Jun 2004 & Wadi Suq & 19.3 & $\underline{\mathrm{Na}}-\mathrm{Mg}-\underline{\mathrm{Cl}}-\mathrm{SO}_{4}$ \\
\hline & Jan 2011 & Wadi Suq & 19.3 & $\underline{\mathrm{Na}}-\mathrm{Mg}-(\mathrm{Ca})-\underline{\mathrm{Cl}}-\mathrm{SO}_{4}$ \\
\hline & Jan 2012 & Wadi Suq & 19.3 & $\underline{\mathrm{Na}}-\mathrm{Mg}-(\mathrm{Ca})-\underline{\mathrm{Cl}}-\left(\mathrm{SO}_{4}\right)$ \\
\hline \multirow[t]{3}{*}{ D7 } & Jan 2005 & Wadi Suq & 20.0 & $\underline{\mathrm{Na}}-\underline{\mathrm{Cl}}$ \\
\hline & Jan 2011 & Wadi Suq & 20.0 & $\underline{\mathrm{Na}}-(\mathrm{Ca})-(\mathrm{Mg})-\underline{\mathrm{Cl}}-\mathrm{SO}_{4}$ \\
\hline & Jan 2012 & Wadi Suq & 20.0 & $\underline{\mathrm{Na}}-(\mathrm{Mg})-\underline{\mathrm{Cl}}-\left(\mathrm{SO}_{4}\right)$ \\
\hline \multirow[t]{2}{*}{ D8 } & Jun 2004 & Wadi Suq & 24.8 & $\underline{\mathrm{Na}}-\mathrm{Mg}-(\mathrm{Ca})-\underline{\mathrm{Cl}}-\mathrm{HCO}_{3}-\left(\mathrm{SO}_{4}\right)$ \\
\hline & Jan 2011 & Wadi Suq & 24.8 & $\underline{\mathrm{Na}}-\mathrm{Mg}-(\mathrm{Ca})-\underline{\mathrm{Cl}}-\mathrm{SO}_{4}-\left(\mathrm{HCO}_{3}\right)$ \\
\hline \multirow[t]{3}{*}{ D9 } & Jun 2004 & Wadi Suq & 28.3 & $\mathrm{Na}-\mathrm{Mg}-(\mathrm{Ca})-\mathrm{HCO}_{3}-\mathrm{Cl}-\mathrm{SO}_{4}$ \\
\hline & Jan 2005 & Wadi Suq & 28.3 & $\mathrm{Na}-\mathrm{Mg}-(\mathrm{Ca})-\mathrm{HCO}_{3}-\mathrm{Cl}-\mathrm{SO}_{4}$ \\
\hline & Jan 2011 & Wadi Suq & 28.3 & $\mathrm{Mg}-\mathrm{Na}-(\mathrm{Ca})-\mathrm{Cl}-\mathrm{HCO}_{3}-\mathrm{SO}_{4}$ \\
\hline \multirow[t]{2}{*}{ D10 } & Jun 2004 & WS, north & 8.0 & $\underline{\mathrm{Na}}-\mathrm{Ca}-(\mathrm{Mg})-\mathrm{Cl}-\mathrm{SO}_{4}-\left(\mathrm{HCO}_{3}\right)$ \\
\hline & Jan 2005 & WS, north & 8.0 & $\underline{\mathrm{Na}}-\mathrm{Ca}-(\mathrm{Mg})-\mathrm{Cl}-\mathrm{SO}_{4}-\left(\mathrm{HCO}_{3}\right)$ \\
\hline \multirow[t]{2}{*}{ Surface water } & Jan 2011 & Wadi al Jizi & 31.0 & $\mathrm{Mg}-\mathrm{Na}-(\mathrm{Ca})-\mathrm{Cl}-\mathrm{HCO}_{3}-\left(\mathrm{SO}_{4}\right)$ \\
\hline & Jan 2012 & Wadi al Jizi & 31.0 & $\mathrm{Mg}-\mathrm{Na}-(\mathrm{Ca})-\mathrm{Cl}-\mathrm{HCO}_{3}-\left(\mathrm{SO}_{4}\right)$ \\
\hline \multirow[t]{4}{*}{ D13 } & Jun 2004 & Wadi al Jizi & 4.5 & $\mathrm{Na}-\mathrm{Ca}-\mathrm{Mg}-\mathrm{SO}_{4}-\mathrm{HCO}_{3}-(\mathrm{Cl})$ \\
\hline & Jan 2005 & Wadi al Jizi & 4.5 & $\underline{\mathrm{Na}}-\mathrm{Ca}-\mathrm{Mg}-\mathrm{SO}_{4}-\mathrm{Cl}-\mathrm{HCO}_{3}$ \\
\hline & Jan 2011 & Wadi al Jizi & 4.5 & $\mathrm{Na}-\mathrm{Ca}-\mathrm{Mg}-\mathrm{SO}_{4}-\mathrm{HCO}_{3}-(\mathrm{Cl})$ \\
\hline & Jan 2012 & Wadi al Jizi & 4.5 & $\mathrm{Na}-\mathrm{Ca}-\mathrm{Mg}-\mathrm{SO}_{4}-\mathrm{HCO}_{3}-\mathrm{Cl}$ \\
\hline Seawater & Jan 2005 & Majess (east WS) & 31.2 & $\underline{\mathrm{Na}}-\mathrm{Mg}-\underline{\mathrm{Cl}}$ \\
\hline \multirow[t]{2}{*}{ Background ophiolite } & 1997-1999 & Jabal Akhdar-Adam Mountains area & Min & $\underline{\mathrm{Mg}}-(\mathrm{Na})-(\mathrm{Ca})-\mathrm{HCO}_{3}-(\mathrm{Cl})-\left(\mathrm{SO}_{4}\right)$ \\
\hline & & & $\operatorname{Max}$ & $\underline{\mathrm{Mg}}-\mathrm{Na}-(\mathrm{Ca})-\mathrm{Cl}-\mathrm{HCO}_{3}-\left(\mathrm{SO}_{4}\right)$ \\
\hline \multirow[t]{2}{*}{ Background alluvium } & $1996-1998$ & Batinah Plain & Min & $\mathrm{Mg}-\mathrm{Ca}-\mathrm{Na}-\underline{\mathrm{HCO}_{3}}-\mathrm{Cl}-\left(\mathrm{SO}_{4}\right)$ \\
\hline & & & Max & $\mathrm{Mg}-\mathrm{Na}-\mathrm{Ca}-\mathrm{HCO}_{3}-\mathrm{Cl}-\left(\mathrm{SO}_{4}\right)$ \\
\hline
\end{tabular}


Table 1 continued

\begin{tabular}{|c|c|c|c|c|c|c|c|c|}
\hline Borehole & Sampling date & $\mathrm{Al}$ & As & $\mathrm{Cd}$ & $\mathrm{Cr}_{\text {tot }}$ & $\mathrm{Cu}$ & $\mathrm{Fe}_{\text {tot }}$ & $\mathrm{Ni}$ \\
\hline WHO guidelines & 2011 & & 0.01 & 0.003 & 0.05 & 2 & & 0.07 \\
\hline \multirow[t]{2}{*}{ D1 } & Jun 2004 & n.a. & n.a. & 0.09 & 0.07 & 0.09 & 0.50 & 0.7 \\
\hline & Jan 2005 & n.a. & n.a. & $<0.02$ & $<0.02$ & 0.2 & 0.64 & 0.08 \\
\hline MW2 & Jan 2011 & $<0.05$ & $<0.05$ & $<0.02$ & $<0.02$ & $<0.05$ & $<0.05$ & $<0.05$ \\
\hline \multirow[t]{2}{*}{ D2 } & Jun 2004 & n.a. & n.a. & 0.06 & 0.07 & 0.18 & 1.26 & 0.6 \\
\hline & Jan 2005 & n.a. & n.a. & $<0.02$ & $<0.02$ & 0.2 & 0.48 & 0.08 \\
\hline \multirow[t]{4}{*}{ D3 } & Jun 2004 & n.a. & n.a. & 0.02 & 0.02 & 0.02 & 0.27 & 0.2 \\
\hline & Jan 2005 & n.a. & n.a. & $<0.02$ & $<0.02$ & 0.02 & 0.16 & 0.3 \\
\hline & Jan 2011 & 0.05 & $<0.05$ & $<0.02$ & $<0.02$ & $<0.05$ & 0.17 & $<0.05$ \\
\hline & Jan 2012 & $<0.05$ & $<0.05$ & $<0.02$ & $<0.02$ & $<0.05$ & 0.18 & $<0.05$ \\
\hline \multirow[t]{3}{*}{$\mathrm{D} 4 \mathrm{~S}$} & Jan 2005 & n.a. & n.a. & $<0.02$ & $<0.02$ & 0.02 & 0.08 & 0.04 \\
\hline & Jan 2011 & $<0.05$ & $<0.05$ & $<0.02$ & $<0.02$ & $<0.05$ & $<0.05$ & $<0.05$ \\
\hline & Jan 2012 & $<0.05$ & $<0.05$ & $<0.02$ & $<0.02$ & $<0.05$ & $<0.05$ & $<0.05$ \\
\hline \multirow[t]{3}{*}{ D4D } & Jun 2004 & n.a. & n.a. & $<0.02$ & 0.06 & 0.1 & 17.20 & 0.2 \\
\hline & Jan 2011 & 0.73 & $<0.05$ & $<0.02$ & $<0.02$ & 0.11 & 0.73 & $<0.05$ \\
\hline & Jan 2012 & $<0.05$ & $<0.05$ & $<0.02$ & $<0.02$ & $<0.05$ & 0.09 & $<0.05$ \\
\hline \multirow[t]{3}{*}{ D5 } & Jun 2004 & n.a. & n.a. & 0.03 & $<0.02$ & 0.12 & 0.90 & 0.3 \\
\hline & Jan 2005 & n.a. & n.a. & $<0.02$ & $<0.02$ & 0.03 & 30.60 & 0.07 \\
\hline & Jan 2011 & 0.47 & $<0.05$ & $<0.02$ & $<0.02$ & $<0.05$ & 1.70 & $<0.05$ \\
\hline \multirow[t]{4}{*}{ D6S } & Jun 2004 & n.a. & n.a. & 0.02 & $<0.02$ & 0.02 & 0.30 & 0.2 \\
\hline & Jan 2005 & n.a. & n.a. & $<0.02$ & $<0.02$ & $<0.02$ & 0.20 & 0.03 \\
\hline & Jan 2011 & $<0.05$ & $<0.05$ & $<0.02$ & $<0.02$ & $<0.05$ & $<0.05$ & $<0.05$ \\
\hline & Jan 2012 & $<0.05$ & $<0.05$ & $<0.02$ & $<0.02$ & $<0.05$ & 0.07 & $<0.05$ \\
\hline \multirow[t]{2}{*}{ D6D } & Jan 2011 & $<0.05$ & $<0.05$ & $<0.02$ & $<0.02$ & $<0.05$ & $<0.05$ & $<0.05$ \\
\hline & Jan 2012 & 0.8 & $<0.05$ & $<0.02$ & $<0.02$ & $<0.05$ & 6.30 & 0.08 \\
\hline \multirow[t]{3}{*}{ W3 } & Jun 2004 & n.a. & n.a. & $<0.02$ & $<0.02$ & $<0.02$ & 3.38 & $<0.02$ \\
\hline & Jan 2011 & $<0.05$ & $<0.05$ & $<0.02$ & $<0.02$ & $<0.05$ & $<0.05$ & $<0.05$ \\
\hline & Jan 2012 & n.a. & n.a. & $<0.02$ & $<0.02$ & $<0.05$ & 3.90 & $<0.05$ \\
\hline \multirow[t]{3}{*}{ D7 } & Jan 2005 & n.a. & n.a. & $<0.02$ & $<0.02$ & $<0.02$ & 1.20 & $<0.02$ \\
\hline & Jan 2011 & $<0.05$ & $<0.05$ & $<0.02$ & $<0.02$ & $<0.05$ & $<0.05$ & $<0.05$ \\
\hline & Jan 2012 & $<0.05$ & $<0.05$ & $<0.02$ & $<0.02$ & $<0.05$ & $<0.05$ & $<0.05$ \\
\hline \multirow[t]{2}{*}{ D8 } & Jun 2004 & n.a. & n.a. & $<0.02$ & $<0.02$ & $<0.02$ & 0.20 & $<0.02$ \\
\hline & Jan 2011 & $<0.05$ & $<0.05$ & $<0.02$ & $<0.02$ & $<0.05$ & $<0.05$ & $<0.05$ \\
\hline \multirow[t]{3}{*}{ D9 } & Jun 2004 & n.a. & n.a. & $<0.02$ & $<0.02$ & $<0.02$ & $<0.05$ & 0.07 \\
\hline & Jan 2005 & n.a. & n.a. & $<0.02$ & $<0.02$ & $<0.02$ & $<0.05$ & $<0.02$ \\
\hline & Jan 2011 & $<0.05$ & $<0.05$ & $<0.02$ & $<0.02$ & $<0.05$ & $<0.05$ & $<0.05$ \\
\hline \multirow[t]{2}{*}{ D10 } & Jun 2004 & n.a. & n.a. & $<0.02$ & $<0.02$ & 0.02 & 0.20 & 0.2 \\
\hline & Jan 2005 & n.a. & n.a. & $<0.02$ & $<0.02$ & 0.02 & 0.25 & $<0.02$ \\
\hline \multirow[t]{2}{*}{ Surface water } & Jan 2011 & $<0.05$ & $<0.05$ & $<0.02$ & $<0.02$ & $<0.05$ & $<0.05$ & $<0.05$ \\
\hline & Jan 2012 & $<0.05$ & $<0.05$ & $<0.02$ & $<0.02$ & $<0.05$ & $<0.05$ & $<0.05$ \\
\hline \multirow[t]{4}{*}{ D13 } & Jun 2004 & n.a. & n.a. & $<0.02$ & $<0.02$ & $<0.05$ & 0.10 & $<0.02$ \\
\hline & Jan 2005 & n.a. & n.a. & $<0.02$ & $<0.02$ & $<0.05$ & $<0.05$ & $<0.02$ \\
\hline & Jan 2011 & $<0.05$ & $<0.05$ & $<0.02$ & $<0.02$ & $<0.05$ & $<0.05$ & $<0.05$ \\
\hline & Jan 2012 & $<0.05$ & $<0.05$ & $<0.02$ & $<0.02$ & $<0.05$ & $<0.05$ & $<0.05$ \\
\hline Seawater & Jan 2005 & $<0.05$ & $<0.05$ & $<0.02$ & 0.02 & 0.02 & 0.10 & 0.08 \\
\hline \multirow[t]{2}{*}{ Background ophiolite } & Min & n.k. & n.k. & n.k. & n.k. & n.k. & n.k. & n.k. \\
\hline & Max & n.k. & n.k. & n.k. & n.k. & n.k. & n.k. & n.k. \\
\hline \multirow[t]{2}{*}{ Background alluvium } & Min & n.k. & n.k. & n.k. & n.k. & n.k. & n.k. & n.k. \\
\hline & Max & n.k. & n.k. & n.k. & n.k. & n.k. & n.k. & n.k. \\
\hline
\end{tabular}


Table 1 continued

\begin{tabular}{|c|c|c|c|c|c|c|c|}
\hline Borehole & Sampling date & $\mathrm{Pb}$ & $\mathrm{Zn}$ & TDS & $\begin{array}{l}\delta^{18} \mathrm{O} \\
\% \text { VSMOW }\end{array}$ & $\begin{array}{l}\delta^{2} \mathrm{H} \\
\% \text { VSMOW }\end{array}$ & $\begin{array}{l}{ }^{3} \mathrm{H} \\
\mathrm{TU}\end{array}$ \\
\hline WHO guidelines & 2011 & 0.01 & & 1,000 & & & \\
\hline \multirow[t]{2}{*}{ D1 } & Jun 2004 & 1.84 & 0.04 & 39,569 & 3.28 & 19.0 & n.a. \\
\hline & Jan 2005 & 0.1 & n.a. & 39,418 & 3.35 & 20.0 & $2.3 \pm 0.6$ \\
\hline MW2 & Jan 2011 & $<0.05$ & $<0.20$ & 29,694 & 2.71 & 15.1 & $0.8 \pm 0.6$ \\
\hline \multirow[t]{2}{*}{ D2 } & Jun 2004 & 1.15 & 0.2 & 30,403 & 1.84 & 11.4 & $2.2 \pm 0.9$ \\
\hline & Jan 2005 & 0.05 & n.a. & 31,367 & 1.74 & 13.9 & $2.0 \pm 0.7$ \\
\hline \multirow[t]{4}{*}{ D3 } & Jun 2004 & 0.73 & 0.02 & 11,340 & n.a. & $\mathrm{n} . \mathrm{a}$ & $2.3 \pm 0.9$ \\
\hline & Jan 2005 & 0.04 & n.a. & 14,490 & -0.17 & 7.3 & $1.1 \pm 0.5$ \\
\hline & Jan 2011 & $<0.05$ & 0.26 & 14,988 & -0.62 & -4.1 & $0.6 \pm 0.5$ \\
\hline & Jan 2012 & $<0.05$ & $<0.20$ & 15,975 & -0.69 & -5.0 & $<0.6$ \\
\hline \multirow[t]{3}{*}{$\mathrm{D} 4 \mathrm{~S}$} & Jan 2005 & 0.73 & n.a. & 11,488 & 0.17 & 4.3 & $2.9 \pm 0.7$ \\
\hline & Jan 2011 & $<0.05$ & 0.29 & 10,907 & 0.32 & 2.1 & $2.2 \pm 0.6$ \\
\hline & Jan 2012 & $<0.05$ & $<0.20$ & 10,425 & 0.36 & 1.9 & $1.7 \pm 0.7$ \\
\hline \multirow[t]{3}{*}{ D4D } & Jun 2004 & 0.75 & 0.3 & 4,409 & -0.61 & -1.5 & $1.0 \pm 0.5$ \\
\hline & Jan 2011 & $<0.05$ & $<0.20$ & 6,032 & -0.79 & -6.5 & $<0.6$ \\
\hline & Jan 2012 & $<0.05$ & $<0.20$ & 5,548 & -0.74 & -6.4 & $<0.6$ \\
\hline \multirow[t]{3}{*}{ D5 } & Jun 2004 & 1.39 & 0.2 & 17,106 & 2.06 & 17.1 & $1.0 \pm 0.4$ \\
\hline & Jan 2005 & 0.06 & n.a. & 16,119 & 2.28 & 19.3 & $0.8 \pm 0.5$ \\
\hline & Jan 2011 & $<0.05$ & $<0.20$ & 13,605 & 1.36 & 4.3 & $1.1 \pm 0.4$ \\
\hline \multirow[t]{4}{*}{ D6S } & Jun 2004 & 0.68 & 0.2 & 7,907 & -0.80 & 2.5 & $3.5 \pm 1.0$ \\
\hline & Jan 2005 & 0.03 & n.a. & 8,099 & -0.76 & 3.6 & $4.2 \pm 0.8$ \\
\hline & Jan 2011 & $<0.05$ & $<0.20$ & 7,399 & -0.50 & -0.1 & $2.6 \pm 0.7$ \\
\hline & Jan 2012 & $<0.05$ & $<0.20$ & 7,209 & -0.50 & -0.2 & $1.9 \pm 0.5$ \\
\hline \multirow[t]{2}{*}{ D6D } & Jan 2011 & $<0.05$ & 0.22 & 3,484 & -0.88 & -1.8 & $1.2 \pm 0.4$ \\
\hline & Jan 2012 & $<0.05$ & $<0.20$ & 3,360 & -0.89 & -1.8 & $<0.6$ \\
\hline \multirow[t]{3}{*}{ W3 } & Jun 2004 & $<0.02$ & n.a. & 4,441 & -1.36 & -1.1 & $3.4 \pm 1.0$ \\
\hline & Jan 2011 & $<0.05$ & $<0.20$ & 5,357 & -1.31 & -5.3 & $1.8 \pm 0.5$ \\
\hline & Jan 2012 & $<0.05$ & $<0.20$ & 5,965 & -1.21 & -5.3 & $1.0 \pm 0.5$ \\
\hline \multirow[t]{3}{*}{ D7 } & Jan 2005 & 0.28 & 0.03 & 2,189 & -1.44 & -1.0 & $2.9 \pm 1.1$ \\
\hline & Jan 2011 & $<0.05$ & 0.31 & 5,247 & -1.77 & -7.9 & $<0.6$ \\
\hline & Jan 2012 & $<0.05$ & $<0.20$ & 4,439 & -1.35 & -3.7 & $1.7 \pm 0.6$ \\
\hline \multirow[t]{2}{*}{ D8 } & Jun 2004 & 0.11 & 0.06 & 1,065 & -2.79 & -8.7 & $3.5 \pm 1.0$ \\
\hline & Jan 2011 & $<0.05$ & $<0.20$ & 1,366 & -2.47 & -6.9 & $1.4 \pm 0.5$ \\
\hline \multirow[t]{3}{*}{ D9 } & Jun 2004 & 0.03 & 0.03 & 588 & -0.85 & -1.2 & $0.7 \pm 0.5$ \\
\hline & Jan 2005 & $<0.02$ & n.a. & 549 & -0.99 & -4.6 & $<0.6$ \\
\hline & Jan 2011 & $<0.05$ & $<0.20$ & 531 & -0.68 & 1.2 & $<0.6$ \\
\hline \multirow[t]{2}{*}{ D10 } & Jun 2004 & 0.14 & 0.05 & 1,720 & -0.96 & -1.6 & $3.7 \pm 0.4$ \\
\hline & Jan 2005 & 0.05 & n.a. & 1,592 & -0.60 & 3.5 & $3.8 \pm 0.5$ \\
\hline \multirow[t]{2}{*}{ Surface water } & Jan 2011 & $<0.05$ & $<0.20$ & 1,062 & -0.89 & -1.4 & $1.2 \pm 0.5$ \\
\hline & Jan 2012 & $<0.05$ & $<0.20$ & 1,068 & -0.42 & 1.7 & $0.7 \pm 0.5$ \\
\hline \multirow[t]{4}{*}{ D13 } & Jun 2004 & $<0.02$ & 0.03 & 538 & -0.60 & 5.2 & $2.5 \pm 0.8$ \\
\hline & Jan 2005 & $<0.02$ & n.a & 772 & -1.20 & -1.3 & $1.0 \pm 0.5$ \\
\hline & Jan 2011 & $<0.05$ & $<0.20$ & 908 & -1.39 & -0.4 & $2.0 \pm 0.5$ \\
\hline & Jan 2012 & $<0.05$ & $<0.20$ & 574 & -1.66 & -1.3 & $1.2 \pm 0.8$ \\
\hline Seawater & Jan 2005 & 0.04 & n.a. & 36,685 & 0.93 & 10.1 & n.a. \\
\hline \multirow[t]{2}{*}{ Background ophiolite } & Min & n.k. & n.k. & n.k. & n.k. & n.k. & n.k. \\
\hline & Max & n.k. & n.k. & n.k. & n.k. & n.k. & n.k. \\
\hline \multirow[t]{2}{*}{ Background alluvium } & Min & n.k. & n.k. & n.k. & n.k. & n.k. & n.k. \\
\hline & Max & n.k. & n.k. & n.k. & n.k. & n.k. & n.k. \\
\hline
\end{tabular}

Chemical typology of groundwater according to Jäckli (1970); ranges of natural background compositions according to Matter (2001), Matter et al. (2005), Rathmayr (2000), and Weyhenmeyer (2000; 2002); concentrations in $\mathrm{mg} / \mathrm{L}$ unless stated otherwise

$n . a$. not analysed, $n . k$. not known 
disconnected Wadi al Jizi (Fig. 1), can be considered noncontaminated and represents the background compositional range in the ophiolitic environment of Wadi Suq. As can be seen from Figs. 2, 3, the contamination of Wadi Suq groundwater with respect to its major element composition is typically expressed by elevated concentrations of $\mathrm{Cl}^{-}, \mathrm{Na}^{+}, \mathrm{K}^{+}, \mathrm{Ca}^{2+}, \mathrm{SO}_{4}{ }^{2-}$, and $\mathrm{Mg}^{2+}$.

Geochemical modelling using field $\mathrm{pH}$ measurements reveals that most groundwater samples from Wadi Suq are oversaturated or saturated with respect to calcite and dolomite, but undersaturated with respect to magnesite (Table 2). In the upper section of Wadi Suq, where groundwater flows through ophiolitic rocks, the calculated oversaturation with respect to calcite is surprising as there is little or no calcite in these rocks (Alabaster et al. 1982; Einaudi et al. 2000; Glennie et al. 1974; Lippard 1986; Searl and Cox 1999). This suggests that calcite oversaturation in the groundwater is induced by some process other than natural weathering of bedrock. Such a process could be mixing with seepage water rich in $\mathrm{Ca}^{2+}$ and inherited from the use of seawater $\left(\mathrm{Ca}^{2+} \approx 440 \mathrm{mg} / \mathrm{L}\right)$ for ore processing and/or from the liming of the tailings. These latter impacts are further supported by the calculated saturation with respect to gypsum and the slight undersaturation with respect to celestite in the highly mineralised groundwater near the tailings dam (boreholes D1, MW2 and D2; Table 2). Neither gypsum nor celestite is known to occur in the ophiolitic rocks, and thus the sulphate must be derived from sulphide oxidation in the tailings and $\mathrm{Sr}$ from seawater and/or the liming process to produce these saturation states. Although saturation with respect to dolomite and magnesite accompanied by low $\mathrm{Ca} / \mathrm{Mg}$ ratios is common in evolved groundwater from ophiolitic environments (e.g. Matter et al. 2005), such behaviour is only seen in the less contaminated, naturally-evolved groundwater downstream of Wadi Suq starting about $20 \mathrm{~km}$ from the tailings dam. Equilibrium with dolomite in the alluvial plain sediments is consistent with the mineralogy of the sediments, which frequently contain layers cemented with secondary dolomite and magnesite (e.g. Burns and Matter 1995).

\section{Fate of Metal and Salinity Contamination}

Geochemical Processes at the Contamination Source

Inferring oxidative weathering of sulphide ores as well as low $\mathrm{pH}$ values is important because it explains elevated metal concentrations (i.e. $\mathrm{Cd}, \mathrm{Cr}, \mathrm{Cu}, \mathrm{Fe}, \mathrm{Ni}, \mathrm{Pb}, \mathrm{Zn}$ ) observed in 2001 (JICA and MCI 2001), 2004, and 2005 in boreholes next to the tailings dump (D1, D2, D3; Table 1). Although Fe, and in some boreholes $\mathrm{Zn}$, were still detected in 2011 and 2012 (Table 1), the lack of detectable Cd, Cr, $\mathrm{Cu} \mathrm{Ni}$, and $\mathrm{Pb}$ concentrations in these later sampling campaigns may imply that further oxidation, triggering the release of metals, was largely inhibited by the surface seal installed in 2005. The low amounts of precipitation since the installation of the surface seal may also have potentially contributed to the lower oxidation potential.

In contrast, lowering of metal concentrations by dilution with younger freshwater can be excluded based on the gradually decreasing ${ }^{3} \mathrm{H}$ activities in the highly mineralised groundwater in the neighbourhood of the tailings dump (Table 1). Except for groundwater from boreholes D1 and D5, neither the sealing nor the low amounts of precipitation significantly reduced the salinity of samples collected after the installation of the surface seal. While a certain amount of natural attenuation of metals by adsorption, surface complexation, and secondary mineral formation seems likely, certainly after lowering their release after 2005, no such process accounts for the salinity contamination. It thus appears that the present groundwater contamination in Wadi Suq more than $2 \mathrm{~km}$ downstream of the tailings dam is mainly due to salinity, which is the focus of the next section.

\section{Traceability of the Salinity Contamination}

The source of the salinity contamination is best traceable with the conservative tracers $\mathrm{Cl}^{-}$and $\mathrm{Br}^{-}$. Figure 4 illustrates that the molar $\mathrm{Cl} / \mathrm{Br}$ ratio was more or less constant and equal to the molar ratio of typical seawater for all measurements at all locations. This observation confirms that the primary salinity source resulted from the use of seawater for ore processing. Moreover, the good correlation $(\mathrm{R}=0.98049)$ suggests that neither $\mathrm{Cl}^{-}$nor $\mathrm{Br}^{-}$were significantly involved in any water-rock interaction processes and that the measured concentrations were the result of a mixture between the used seawater and meteoric water or regional, non-saline groundwater. Figure 4 also shows that the sample collected from the borehole closest to the processing plant (D1) yielded higher $\mathrm{Cl}^{-}$and $\mathrm{Br}^{-}$concentration than actual seawater. This is a clear indication that the used seawater was partially evaporated at the processing plant and that the actual source of the contamination was enriched in $\mathrm{Cl}^{-}$and $\mathrm{Br}^{-}$compared to seawater.

Evaporation leads to an enrichment of the heavy water isotopes ${ }^{18} \mathrm{O}$ and ${ }^{2} \mathrm{H}$ in the remaining fluid (Horita and Wesolowski 1994). Accordingly, water isotopic composition $\left(\delta^{18} \mathrm{O}\right.$ and $\left.\delta^{2} \mathrm{H}\right)$ forms an additional important tracer for the salinity plume because once the highly saline fluid infiltrates into the aquifer, further evaporation is unlikely to occur. Thus, plotting $\delta^{18} \mathrm{O}$ versus $\mathrm{Cl}^{-}$concentrations 

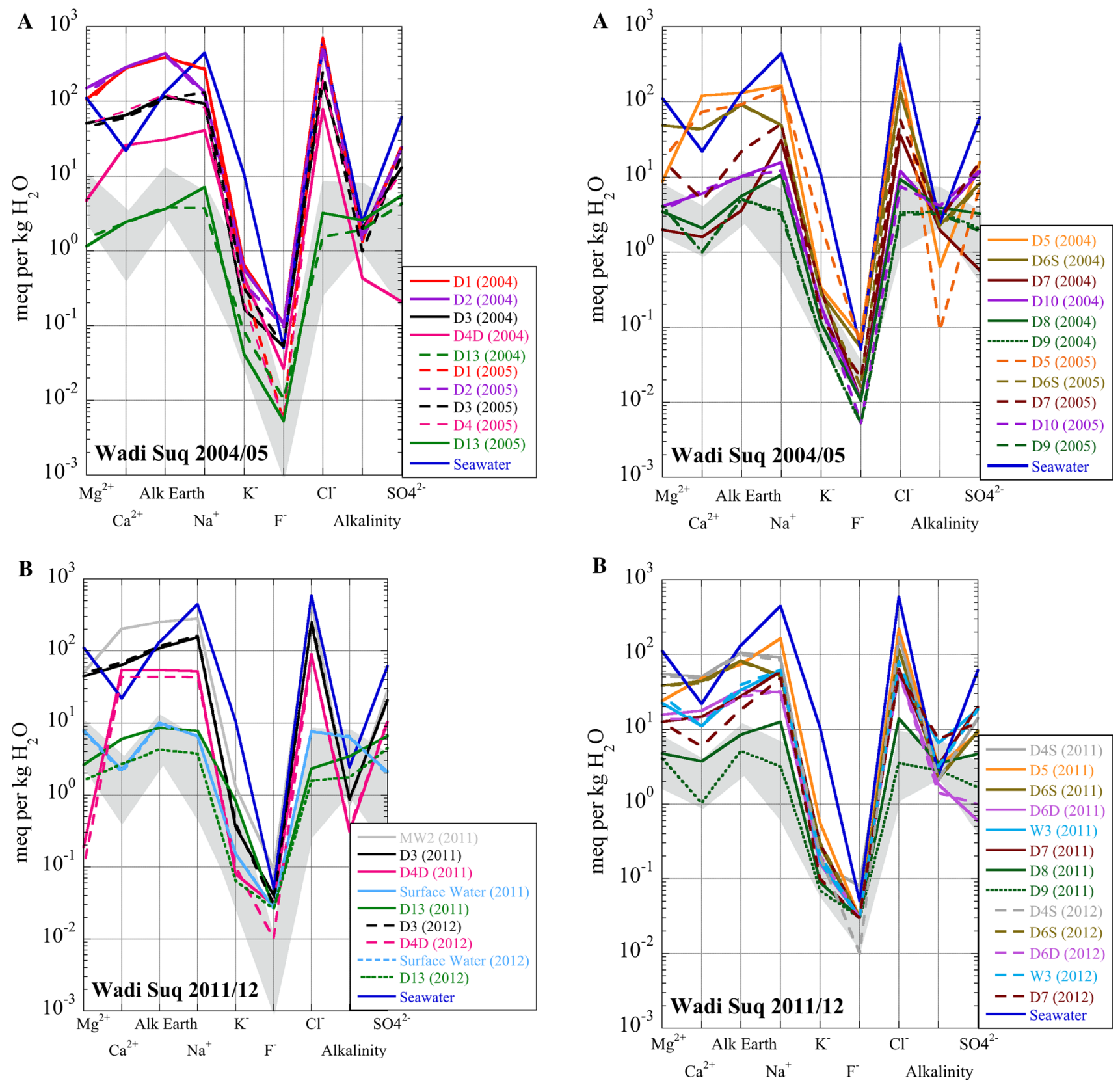

Fig. 2 Schoeller diagrams for water samples from Wadi Suq, Wadi Bani Umar, and Wadi Jizi taken within the ophiolitic rock sequence in the campaigns of 2004/05 (top) and 2011/12 (bottom). The shaded area indicates the compositional range of recent, non-contaminated groundwater in ophiolitic rock aquifers (data from Matter 2001; Matter et al. 2005; Rathmayr 2000; Weyhenmeyer 2000)

normalized to seawater $\mathrm{Cl}^{-}$concentration (Fig. 5a) provided more insight into the origin and fate of the salinity plume. Figure 5a shows two different signatures of constant $\delta^{18} \mathrm{O} / \mathrm{Cl}$ ratios. One occurs in the upstream part of Wadi Suq aquifer, from the tailings dump down to the groundwater of borehole D4, while the second constant $\delta^{18} \mathrm{O} / \mathrm{Cl}$ ratio is observed downstream of borehole D5 until borehole D8. A constant $\delta^{18} \mathrm{O} / \mathrm{Cl}$ ratio implies a variable

Fig. 3 Schoeller diagrams for water samples from Wadi Suq in the alluvial aquifer in the campaigns of 2004/05 (top) and 2011/12 (bottom); the shaded area indicates the compositional range of recent, non-contaminated groundwater in the alluvial aquifer (data from Weyhenmeyer 2000, 2002)

mixture between natural background groundwater $\left(\mathrm{Cl}^{-}\right.$: $10-350 \mathrm{mg} / \mathrm{L}$ and $\delta^{18} \mathrm{O}:-1.7$ to $-0.6 \%$ ) and evaporated seawater as the salinity source $\left(\mathrm{Cl}^{-}:>21044 \mathrm{mg} / \mathrm{L}\right.$ and $\delta^{18} \mathrm{O}:>0.93 \%$ ). The fact that two different constant $\delta^{18} \mathrm{O} /$ $\mathrm{Cl}$ ratios are observed (Fig. 5a) implies the mixture of natural background groundwater with two different salinity sources characterized by evaporation degrees (two different end members) and does not support the idea of a single 
Table 2 Mineral saturation states of groundwater from Wadi Suq and neighbouring localities collected between 2004 and 2012

\begin{tabular}{|c|c|c|c|c|c|c|c|c|}
\hline Borehole & $\begin{array}{l}\text { Sampling } \\
\text { date }\end{array}$ & Calcite & Dolomite & Magnesite & Strontianite & Celestite & Fluorite & Gypsum \\
\hline \multirow[t]{2}{*}{ D1 } & Jun 2004 & 0.45 & -0.10 & -0.70 & -1.40 & -0.10 & -0.20 & -0.10 \\
\hline & Jan 2005 & -0.04 & -0.23 & -0.82 & -1.54 & -0.19 & -2.43 & 0.03 \\
\hline MW2 & Jan 2011 & 0.41 & 0.48 & -0.53 & -1.19 & -0.28 & 0.04 & 0.00 \\
\hline \multirow[t]{2}{*}{ D2 } & Jun 2004 & 0.26 & 0.00 & -0.60 & -0.14 & -0.10 & -0.10 & 0.00 \\
\hline & Jan 2005 & 0.09 & -0.08 & -0.67 & -1.53 & -0.22 & -0.90 & -0.03 \\
\hline \multirow[t]{4}{*}{ D3 } & Jun 2004 & 0.22 & 0.14 & -0.46 & -1.21 & -0.44 & -0.81 & -0.55 \\
\hline & Jan 2005 & 0.34 & 0.13 & -0.47 & -1.15 & -0.25 & -0.83 & -0.44 \\
\hline & Jan 2011 & 0.36 & 0.80 & -0.15 & -0.74 & -0.16 & -0.99 & -0.39 \\
\hline & Jan 2012 & 0.33 & 0.76 & -0.16 & -0.82 & -0.21 & - & -0.36 \\
\hline \multirow[t]{3}{*}{ D4S } & Jan 2005 & 0.24 & 0.08 & -0.52 & -1.55 & -0.78 & -2.77 & -0.57 \\
\hline & Jan 2011 & 0.08 & 0.43 & -0.24 & -1.24 & -0.62 & -0.56 & -0.61 \\
\hline & Jan 2012 & 0.09 & 0.44 & -0.24 & -1.08 & -0.47 & - & -0.62 \\
\hline \multirow[t]{3}{*}{ D4D } & Jun 2004 & 0.22 & -0.85 & -1.27 & -1.69 & -2.51 & -0.10 & -2.32 \\
\hline & Jan 2011 & 0.71 & -0.81 & -2.12 & -1.76 & -1.60 & - & -0.45 \\
\hline & Jan 2012 & 1.03 & - & - & -1.38 & -1.57 & - & -0.49 \\
\hline \multirow[t]{3}{*}{ D5 } & Jun 2004 & 0.35 & -0.90 & -1.50 & -1.00 & 0.10 & -0.10 & -0.30 \\
\hline & Jan 2005 & -1.38 & -0.39 & -0.98 & -0.88 & -0.28 & -0.49 & -0.74 \\
\hline & Jan 2011 & 0.93 & 1.83 & 0.30 & 0.24 & -0.16 & - & -0.79 \\
\hline \multirow[t]{4}{*}{ D6S } & Jun 2004 & 0.34 & 0.30 & -0.30 & -1.20 & -0.70 & -3.06 & -0.80 \\
\hline & Jan 2005 & 0.13 & 0.30 & -0.29 & -1.28 & -0.83 & -2.32 & -0.87 \\
\hline & Jan 2011 & 0.13 & 0.43 & -0.29 & -1.16 & -0.71 & - & -0.73 \\
\hline & Jan 2012 & 0.15 & 0.49 & -0.26 & -1.15 & -0.71 & - & -0.73 \\
\hline \multirow[t]{2}{*}{ D6D } & Jan 2011 & 0.02 & 0.22 & -0.40 & -1.29 & -2.02 & - & -2.03 \\
\hline & Jan 2012 & -0.13 & 0.00 & -0.47 & -1.30 & -1.73 & - & -1.89 \\
\hline \multirow[t]{3}{*}{ W3 } & Jun 2004 & -0.04 & 0.32 & -0.28 & -1.09 & -2.53 & -3.06 & -2.76 \\
\hline & Jan 2011 & 0.26 & 0.65 & -0.20 & -0.76 & -0.35 & -1.48 & -0.66 \\
\hline & Jan 2012 & 0.09 & 0.22 & -0.40 & -1.29 & -0.80 & - & -2.03 \\
\hline \multirow[t]{3}{*}{ D7 } & Jan 2005 & 0.27 & 0.76 & 0.16 & -1.10 & -0.97 & -2.32 & -1.18 \\
\hline & Jan 2011 & 0.53 & 1.58 & 0.45 & -0.55 & -0.60 & -1.69 & -0.84 \\
\hline & Jan 2012 & 0.15 & 0.72 & 0.04 & -0.85 & -0.66 & - & -1.18 \\
\hline \multirow[t]{2}{*}{ D8 } & Jun 2004 & 0.00 & 0.50 & -0.10 & -0.90 & -1.40 & -2.90 & -1.80 \\
\hline & Jan 2011 & 0.00 & 0.33 & -0.27 & -1.16 & -1.31 & - & -1.48 \\
\hline \multirow[t]{3}{*}{ D9 } & Jun 2004 & 0.00 & 0.90 & 0.30 & 0.90 & -1.80 & -2.57 & -2.30 \\
\hline & Jan 2005 & 0.00 & 0.85 & 0.25 & -0.88 & -1.87 & -3.77 & -2.30 \\
\hline & Jan 2011 & 0.00 & 0.81 & 0.21 & -0.94 & -1.93 & - & -2.30 \\
\hline \multirow[t]{2}{*}{ D10 } & Jun 2004 & -0.01 & 0.02 & -0.57 & -1.37 & -1.00 & -2.57 & -0.96 \\
\hline & Jan 2005 & 0.63 & 0.00 & -0.59 & -1.40 & -1.00 & -3.03 & -1.00 \\
\hline \multirow{2}{*}{$\begin{array}{r}\text { Surface } \\
\text { water }\end{array}$} & Jan 2011 & - & - & - & - & - & - & - \\
\hline & Jan 2012 & - & - & - & - & - & - & - \\
\hline \multirow[t]{4}{*}{ D13 } & Jun 2004 & 0.57 & 0.00 & -0.60 & -1.30 & -1.60 & -2.80 & -1.50 \\
\hline & Jan 2005 & 0.22 & -0.11 & -0.59 & -1.65 & -1.80 & -3.40 & -1.46 \\
\hline & Jan 2011 & 0.35 & 0.54 & -0.41 & -1.22 & -1.35 & - & -1.08 \\
\hline & Jan 2012 & 0.40 & 0.77 & -0.23 & -1.01 & -1.56 & - & -1.47 \\
\hline
\end{tabular}

downward migrating salinity plume. In particular, the linear decrease of $\mathrm{Cl}^{-}$concentrations and $\delta^{18} \mathrm{O}$ values over 6 years at borehole D5 is a strong indication for a second salinity source.
Identifying a second salinity source in the vicinity of borehole D5 confirms previous studies (Al-Adawi 1996; JICA and MCI 2001) suggesting that a leak in the seawater pipeline transporting seawater from the sea to the 


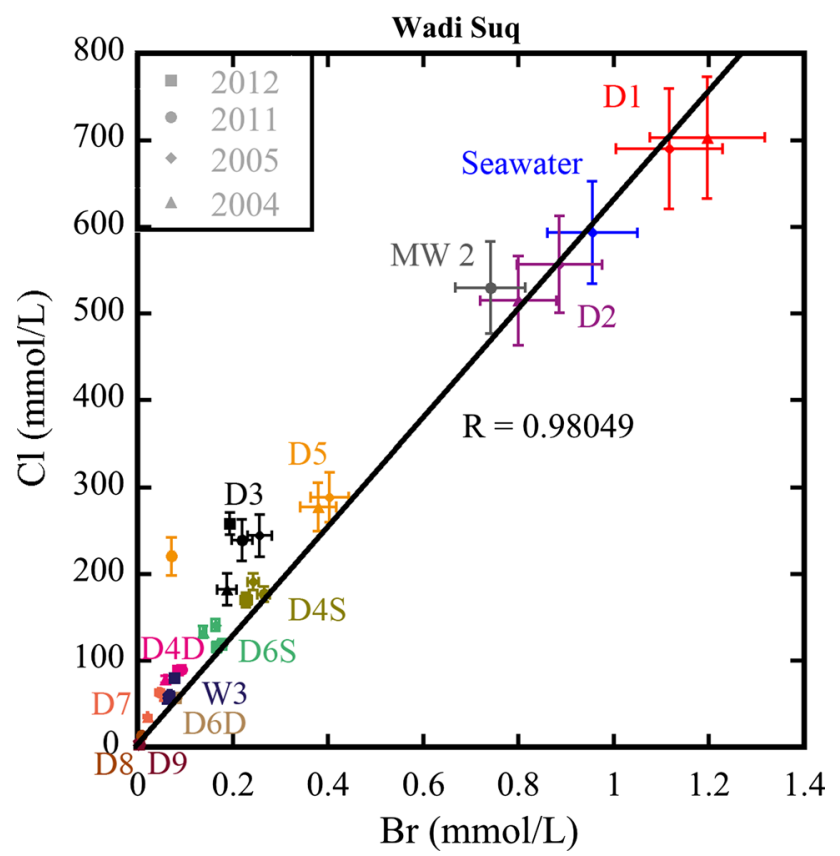

Fig. 4 Concentrations of chloride and bromide in groundwater samples collected In Wadi Suq between 2004 and 2012; error bars indicate the analytical error of \pm 5 to $\pm 10 \%$, depending on the total mineralisation of the groundwater

processing plant caused a salinity plume close to D5. The $\delta^{18} \mathrm{O} / \mathrm{Cl}$ ratios of the two identified salinity sources are unknown, but we assume that they lay on the extrapolated mixing lines (Fig. 5a). The second constraint on the source $\delta^{18} \mathrm{O} / \mathrm{Cl}$ ratio is given by seawater evaporation, typically expressed as a Rayleigh distillation model

$\ln \left[(\delta+1000) /\left(\delta_{i}+1000\right)\right]=\left(\alpha_{\text {evap }}-1\right) \ln f$

where $\delta$ and $\delta_{i}$ are the isotopic oxygen and hydrogen compositions of the two salinity sources and seawater, $f$ is the fraction of seawater remaining, and $\alpha_{\text {evap }}$ is the fractionation factor between seawater and evaporated vapour, defined as:

$\alpha_{\text {evap }}=\frac{R_{\text {vapour }}}{R_{\text {water }}}$

where $R_{\text {water }}$ and $R_{\text {vapour }}$ refer to the ${ }^{2} \mathrm{H} /{ }^{1} \mathrm{H}$ or ${ }^{18} \mathrm{O} /{ }^{16} \mathrm{O}$ ratio in water and the evaporated vapour, respectively. For convenience, fractionation factors $(\alpha)$ are typically expressed as enrichment factors $\varepsilon$ according to:

$\varepsilon=(\alpha-1) \times 1000$

The effective enrichment factor $\varepsilon_{\text {eff }}$ of $\mathrm{O}$ and $\mathrm{H}$ isotopes during evaporation includes an equilibrium $\left(\varepsilon_{e q}\right)$ as well as a kinetic enrichment factor (diffusive factor, $\varepsilon_{\text {diff; }}$, e.g. Clark and Fritz 1997):

$\varepsilon_{e f f}=\varepsilon_{e q}+\varepsilon_{\text {diff }}$
Horita and Wesolowski (1994) reported $\varepsilon_{e q}$ values of $-8.7 \%$ for the enrichment of ${ }^{18} \mathrm{O}$ and of $-62.2 \%$ for the enrichment of ${ }^{2} \mathrm{H}$ in the remaining fluid for similar conditions $\left(\mathrm{T}=40{ }^{\circ} \mathrm{C}\right)$ as observed in Wadi Suq. Gonfiantini (1986) reported the dependence of $\varepsilon_{\text {diff }}$ values of $\mathrm{O}$ and $\mathrm{H}$ isotopes on humidity as:

$\varepsilon_{\text {diff }{ }^{18} O}=14.2 \times(1-h)$

$\varepsilon_{\text {diff }}^{2} H=12.5 \times(1-h)$

where $\varepsilon_{\text {diff }}$ is the diffusion-related enrichment factor and $h$ is the humidity. Based on the low average humidity of $\approx 30 \%$, this yields $\varepsilon_{\text {diff }}$ values of $-9.94 \%$ for oxygen and $-8.75 \%$ for hydrogen in the Wadi Suq area. Applying Equation 4 in combination with the reported $\varepsilon_{e q}$ and estimated $\varepsilon_{\text {diff }}$ values yields effective enrichment factors of about $-18.6 \%$ for ${ }^{18} \mathrm{O}$ and about $-70.9 \%$ for ${ }^{2} \mathrm{H}$. In order to plot the Rayleigh trend (Fig. 5b), the remaining liquid water fraction $f$ (Eq. 1) was converted to the $\mathrm{Cl}^{-}$concentrations normalised to seawater according to:

$C l_{\text {Norm }}=1 / f$

where $\mathrm{Cl}_{\text {Norm }}$ is the normalized chloride concentrations (i.e. $\mathrm{Cl}_{\text {sample }} / \mathrm{Cl}_{\text {sewater }}$ ).

Starting at the initial composition of seawater and subsequently following the Rayleigh trend (Fig. 5b), two interception points with the two mixing lines are observed. These interception points implicate the initial $\delta^{18} \mathrm{O} / \mathrm{Cl}$ ratio of the two salinity contamination sources (Fig. 5b, sources 1 and 2). Following Eq. 7, normalized $\mathrm{Cl}^{-}$concentrations can be expressed as remaining water fraction $\mathrm{f}$ and magnitude of evaporation $(1-\mathrm{f})$. The $\delta^{18} \mathrm{O} / \mathrm{Cl}$ ratio of the salinity contamination at the tailings dump was close to that of borehole D1 (Fig. 5b), revealing that the chemical groundwater composition of this borehole can be used as a proxy for the composition of the salinity source at the tailings dump (source 1 in Fig. 5b). Using seawater $\delta^{18} \mathrm{O}$ and $\delta^{2} \mathrm{H}$ values and the ones measured at D1 in conjunction with Eq. 1 yields an evaporation degree of $12 \%\left(\delta^{18} \mathrm{O}\right)$ and $14 \%\left(\delta^{2} \mathrm{H}\right)$, respectively. These similar values suggest that their average $(13 \pm 1 \%)$ is a good approximation for the magnitude of evaporation at this particular salinity contamination (i.e. tailings dump).

The salinity contamination sources that affect the lower part of the Wadi Suq aquifer (borehole D5-D8), are much more enriched in ${ }^{18} \mathrm{O}$ and $\mathrm{Cl}^{-}$(Fig. 5b). However, no measured groundwater composition can be used as a proxy for this contamination source. We estimated the corresponding $\delta^{18} \mathrm{O}$ and normalized $\mathrm{Cl}^{-}$concentration by visually inspecting Fig. 5b, yielding values of 12.83 and $1.89 \%$, respectively. Using these values in conjunction with Eqs. 1-7 implies a magnitude of evaporation of about 
A

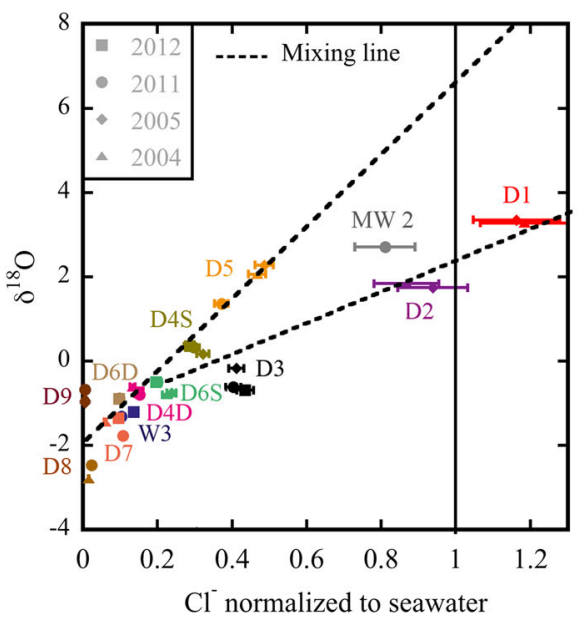

B Wadi Suq

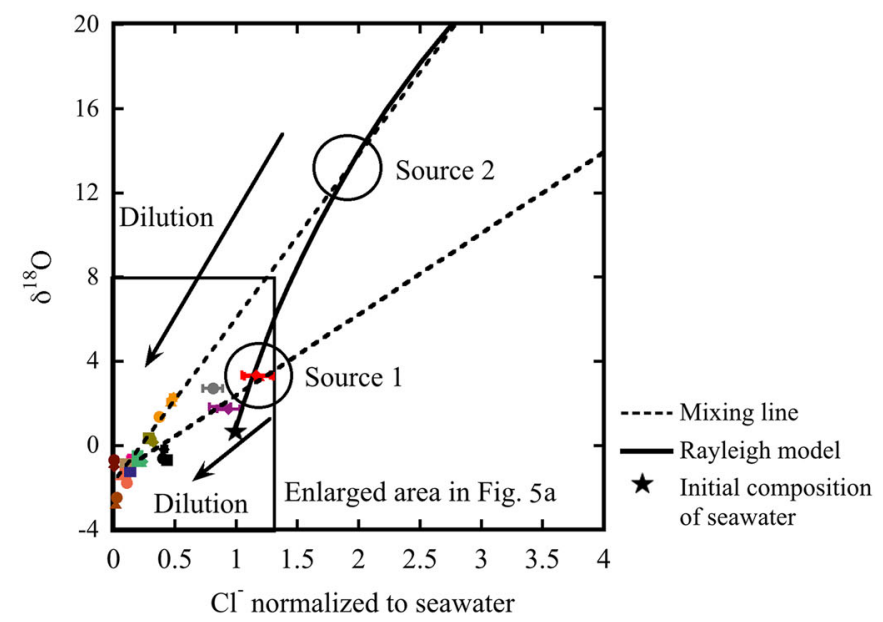

Fig. 5 a $\delta^{18} \mathrm{O}$ versus chloride concentration normalised to seawater of groundwater samples collected between 2004 and 2012, the dashed lines indicate possible mixing lines. b The solid line indicates the Rayleigh fractionation trend line of evaporating seawater with the

$53 \%$ for the pipeline spill. The significantly larger evaporation is explained by proposing that the spilled seawater infiltrated slowly into the groundwater because of slightly permeable sediments (e.g. clays), allowing much of it to evaporate.

\section{Time Dependent Extension of Salinity Contamination}

To evaluate the evolution of the salinity contamination with time, $\mathrm{Cl}^{-}$concentrations are plotted as a function of the distance from the tailings dump (Fig. 6). The maximum chloride concentration in the groundwater next to the tailings dump (D1) was reached in 2000, when the concentration was significantly higher than that of seawater (Fig. 6). High $\mathrm{Cl}^{-}$ concentrations are related to the use of seawater as ore processing fluid from 1983 to 1993 . Strong precipitation events in the 1980s and 1990s (Fig. S-1) most likely enhanced flushing of this seawater and thus saline contamination of the aquifer. The observation that two different salinity plumes can be geochemically distinguished makes it difficult to assess whether the salinity plume induced by seepage from the tailings pond has yet reached the location of the second salinity source, i.e. the pipeline spill close to borehole D5 (Fig. 6). Historical data indicate that groundwater in borehole D4 $(8.5 \mathrm{~km}$ from the tailings dam) was already contaminated in 1996 (Fig. 6). This suggests that the groundwater flow velocity was on the order of $1 \mathrm{~km} /$ year at least in this part of the wadi. In 2011 and 2012, the front of the salinity plume was already observed at borehole D8, $24.8 \mathrm{~km}$ from the tailings dam. Samples collected from this borehole in 2004 indicated no contamination, thus indicating that the breakthrough occurred sometimes between 2004 and star indicating the initial composition of seawater. The interceptions between the groundwater mixing lines and the Rayleigh fractionation trend line indicate the compositions of the two different salinity sources that contaminate Wadi Suq groundwater

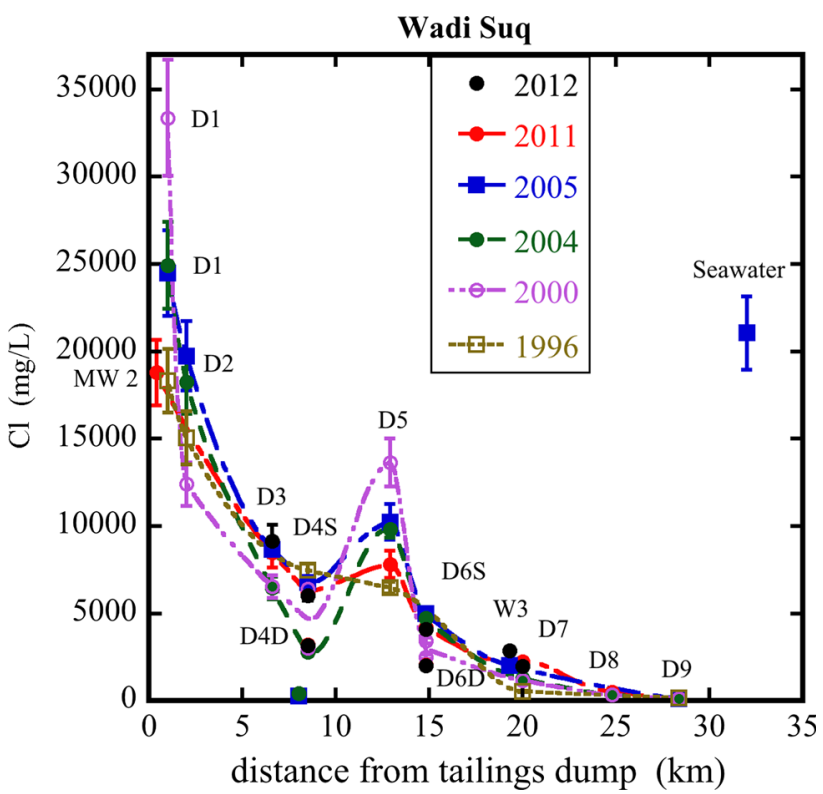

Fig. 6 Chloride concentrations versus distance from tailings dam in groundwater samples collected in 1996 (MWR), 2000 (JICA and MCI), and between 2004 and 2012 (this study). The dashed lines indicate interpolation between groundwater from the shallow boreholes. Error bars indicate the analytical error of \pm 5 to $\pm 10 \%$, depending on the total mineralisation of the groundwater

2011. Assuming that the contamination in borehole D8 stems from a pipeline spill between 1983 and 1993 close to borehole D5, a groundwater flow velocity of about $2 \mathrm{~km} / \mathrm{year}$ would be derived for the lower part of Wadi Suq. This would indicate that borehole D9, $28 \mathrm{~km}$ from the tailings dam, will be affected by the salinity plume in about 5 years. 
After 2000, $\mathrm{Cl}^{-}$concentrations decreased only in groundwater sampled next to the tailings dam (boreholes D1 and D2) and close to the inferred pipeline spill, with the decease being between 30 and $50 \%$ (Fig. 6). In boreholes D1 and D2, such decreases can be related to low amounts of precipitation during the last decade and the surface sealing of the tailings pond, but this does not account for borehole D5 further downstream based on available estimates for the groundwater flow velocity. It seems more likely that the decrease is related to the cessation of seawater infiltration after abandonment of the seawater pipeline. However, additional sampling during wet periods is required to further confirm these statements and to assess the impact and efficiency of the surface sealing of the tailings on the salinity and minor metals plume.

\section{Conclusions}

Long-term monitoring of groundwater of Wadi Suq was conducted to assess the impact of having used seawater at the sulphide ore processing plant. Chemical water analyses including metals and stable $\left(\delta^{18} \mathrm{O}, \delta^{2} \mathrm{H}\right)$ and radiogenic $\left({ }^{3} \mathrm{H}\right)$ isotope measurements show highly saline seepage water with elevated metal concentrations $(\mathrm{Cd}, \mathrm{Cr}, \mathrm{Cu} \mathrm{Ni}$, $\mathrm{Pb}$, and $\mathrm{Zn}$ ) infiltrating into the groundwater until 2005. From then onwards, salinity and metal concentrations decreased close to the tailings pond, presumably due to lower amounts of precipitation and the installation of a HDPE surface seal, though the relative contribution of these factors cannot be established with the present data. Despite the local decrease in salinity and metal concentrations, groundwater in Wadi Suq does not meet WHO drinking water guidelines up to $25 \mathrm{~km}$ from the tailings pond. Molar $\mathrm{Cl} / \mathrm{Br}$ ratios combined with isotope data indicate that seawater was indeed the primary contamination source. The $\delta^{18} \mathrm{O} / \mathrm{Cl}$ ratios further show that a secondary salinity hotspot related to leakage of the seawater pipeline exists about $13 \mathrm{~km}$ from the tailings dam, in addition to the primary hotspot at the tailings pond.

The observation that groundwater concentrations are far from the WHO drinking water standard implies that the use of seawater for ore processing has the potential of contaminating almost an entire aquifer for at least several decades. This is especially critical in arid regions like the Sohar area, where groundwater recharge is low. Based on groundwater flow velocity estimates and the assumption of no future contamination, it will take at least 30 years until the contamination is flushed from the aquifer.

Acknowledgments We thank the Ministry of Water Resources, the Oman Mining Company, Sultanate of Oman, and the Swiss Academy of Sciences (SCNAT+) for financial support and for access to the
Lasail mining site and the boreholes in Wadi Suq. Analytical support by Dr. Sabah (Directorate General of Minerals), R. Mäder, P. Bähler, and S. Weissen (Institute of Geological Sciences, University of Bern) is highly acknowledged. The constructive comments by two anonymous reviewers greatly helped improve the manuscript.

\section{References}

Alabaster T, Pearce JA, Malpas J (1982) The volcanic stratigraphy and petrogenesis of the Oman ophiolith complex. Contr Miner Petrol 81:168-183

Al-Adawi A (1996) Groundwater pollution and remediation in Wadi Suq. Ministry of Water Resources, Water Protection Dept, Muscat

Al-Sulaimani MYN (2005) Environmental geochemistry of the Sohar Mine area, Sultanate of Oman. MS Thesis, Inst of Geological Sciences, Univ of Bern, Switzerland

Ball JW, Nordstrom DK (1991) User's manual for WATEQ4F, with revised thermodynamic data base and test cases for calculating speciation of major, trace, and redox elements in natural waters. USGS, Reston

Béchennec F, Le Métour J, Rabu D, Villey M, Beurrier M (1988) The Hawaisina Basin: a fragment of a starved passive continental margin, thrust over the Arabian Platform during obduction of the Sumail Nappe. Tectonophysics 151:323-343

Bigham JM, Nordstrom DK (2000) Iron and aluminum hydroxysulfates from acid sulfate waters. In: Alpers CN, Jambor JL, Nordstrom DK (ed), Sulfate minerals: crystallography, geochemistry, and environmental significance. Rev Mineral Geochem 40:351-403

Bladh KW (1982) The formation of goethite, jarosite and alunite during the weathering of sulfide-bearing felsic rocks. Econ Geol 77:176-184

Breitenbach AJ, Smith ME (2006) Overview of geomembrane history in mining industry. Presentation, 8th bi-annual $\mathrm{Mtg}$ of the International Geosynthetics Soc (8IGS), Japan

Burns SJ, Matter A (1995) Geochemistry of carbonate cements in surficial alluvial conglomerates and their paleoclimatic implications. Sultanate of Oman. J Sed Res A65(1):170-177

Byrne P, Wood PJ, Reid I (2011) The impairment of river systems by metal mine contamination: a review including remediation options. Crit Rev Environ Sci Tec 42:2017-2077

Clark F, Fritz P (1997) Environmental isotopes in hydrogeology. CRC Press, Boca Raton

Eggimann M (2008) Geochemical aspects of municipal solid waste incineration bottom ash and implications for disposal. Diss Thesis, Univ of Bern, Switzerland

Einaudi F, Pezard PA, Cochemé JJ, Coulon C, Laverne C, Godard M (2000) Petrography geochemistry and physical properties of a continuous extrusive section from the Sarami Massif, Semail Ophiolite. Mar Geophysl Res 21:387-407

Gibb A, Partners Sir (1974) Water resources survey of northern Oman. Ministry of Water Resources, Muscat

Glennie KW, Boeuf MGA, Hughes Clark MW, Moody-Stuart M, Pilaar WFH, Reinhardt BME (1974) Geology of Oman Mountains. Royal Dutch Geol Mining Soc, Verh Kon Ned Geol Minjnb Gen

Gonfiantini R (1986) Environmental isotopes in lake studies. In: Fontes F, Fontes JC (eds) Handbook of environmental isotope geochemistry, vol 2, the terrestrial environment, B. Elsevier, Amsterdam, pp 113-168

Horita J, Wesolowski DJ (1994) Liquid-vapor fractionation of oxygen and hydrogen isotopes of water from the freezing to 
the critical temperature. Geochim Cosmochim Acta 58:3425-3437

Jäckli H (1970) Kriterien zu Klassifikation von Grundwassvorkommen. Ecl Geol Helv 63:389-434

JICA, MCI (2001) The feasibility study on mine pollution control in Sohar Mine Area, Sultanate of Oman. Mitsubishi Materials Natural Resources Development Corp, E\&E Solutions Inc, Tokyo, Japan

Johnson DB, Hallberg KB (2005) Acid mine drainage remediation options: a review. Sci Tot Environ 338:3-14

Lakey R, Easton P, Al Hinai H (1995) Eastern Batinah resource assessment-numerical modeling. Report of the Ministry of Water Resources, Muscat, Oman

Le Métour J (1995) Geology and mineral wealth of the Sultanate of Oman. Geological Doc, Ministry of Petroleum of Minerals, Muscat, Oman

Li MG, Aube BC, St-Arnaud LC (1997) Considerations in the use of shallow water covers for decommissioning reactive tailings. In: Proceedings of 4th international conference on acid rock drainage, Vancouver, BC, Canada, vol I, p 115-130

Lippard SJ (1986) The ophiolite of northern Oman. Blackwell Scientific Publ, Oxford

Matter JM (2001) Geochemical evolution and hydrodynamics of groundwaters in the alluvial aquifer of the Dakhiliya Area, Sultanate of Oman. PhD Thesis, Swiss Federal Inst of Technology Zurich, Switzerland

Matter JM, Waber HN, Loew S, Matter M (2005) Recharge areas and geochemical evolution of groundwater in an alluvial aquifer system in the Sultanate of Oman. Hydrogeol J 14:203-224

McGregor RG, Blowes DW (2002) The physical, chemical and mineralogical properties of three cemented layers within sulfidebearing mine tailings. J Geochem Expl 76:195-207

MWR (1996) Groundwater pollution and remediation in Wadi Suq. Ministry of Water Resources, Water Protection Dept, Muscat

Nordstrom, DK, Plummer LN, Langmuir D, Busenberg E, May HM, Jones BF, Parkhurst DL (1990) Revised chemical equilibrium data for major water-mineral reactions and their limitations. In: Melchior DC, Bassett RL (ed) Chemical modelling of aqueous systems II, ACS Symposium Series 416, Am Chem Soc, Washington DC, USA, p 398-413

Nordstrom DK, Wilde FD (1998) Reduction-oxidation potential (electrode method). Field Measurements, vol 9, Ch A6, USGS techniques of water-resources investigations, Reston, VA, USA

Parkhurst DL, Appelo CAJ (1999) User's guide to PHREEQC (version 2) - a computer program for speciation, batch-reaction, one-dimensional transport, and inverse geochemical calculations. USGS WRI Report 99-4259, Reston, VA, USA

Peters T, Nicolas A, Coleman RGE (eds) (1990) Ophiolite genesis and evolution of the oceanic lithosphere. Series: Petrology and structural geology. In: Proceedings Ophiolite Conference, vol 5, Kluwer Academic Publ, Dordrecht, The Netherlands

Rathmayr B (2000) Geology and hydrogeology of the Birkat al Mawz-Izki Area, Sultanate of Oman. MS Thesis, Inst of Geological Sciences, Univ of Bern, Switzerland

Searl M, Cox J (1999) Tectonic setting, origin and obduction of the Oman ophiolith. Geol Soc Am Bull 111:104-122

Sharama RS, Al-Busaidi TS (2001) Pollution due to a tailings dam. Eng Geol 60:235-244

Weyhenmeyer CE (2000) Origin and evolution of groundwater in the alluvial aquifer of the Eastern Batinah Coastal Plain, Sultanate of Oman. PhD Thesis, Inst of Geological Sciences, Univ of Bern, Switzerland

Weyhenmeyer CE (2002) Groundwater evolution in an arid coastal region of the Sultanate of Oman based on geochemical and isotopic tracers. In: Stober I, Bucher K (eds) Water-rock interaction. Kluwer Academic Publ, Amsterdam, The Netherlands, ISBN13: 9781402004971, p 1-38

Weyhenmeyer CE, Burns SJ, Waber HN, Macumber PG, Matter A (2002) Isotope study of moisture sources, recharge areas, and groundwater flow paths within the eastern Batinah coastal plain, Sultanate of Oman. Water Resour Res 38(10):1184-1206. doi:10.1029/2000WR000149

WHO (2011) Guidelines for drinking-water quality, 4th edn. WHO Press, Malta 